وعي المرأة بأساليب هواجهة الضغوط و علاقته بالاستقرار الأسري

\author{
اعداد \\ |. م.د نحلاء سيد حسين \\ أستاذ مساعد بقسم إدارة مؤسسات الأسرة و الطفولة \\ كلية الاقتصاد المنزلي - جامعة حلوان
}

مجلة بحوث التربية النوعية ـ جامعة المنصورة

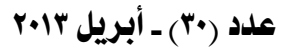




\section{وعي المرأة بأساليب هواجهة الضغوط و علاقته بالاستقرار الأسري}

إعداد

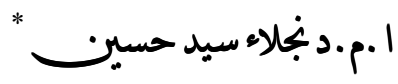

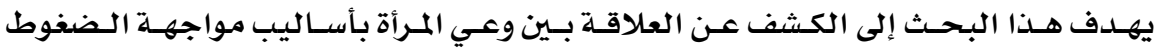

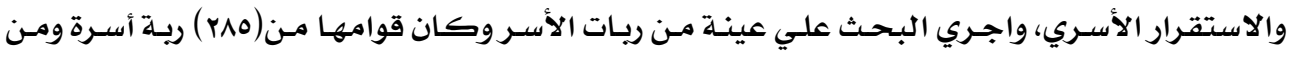

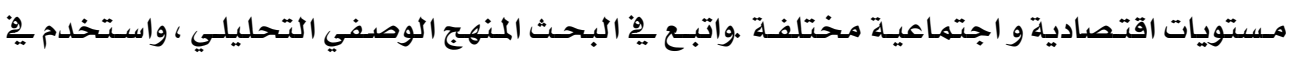

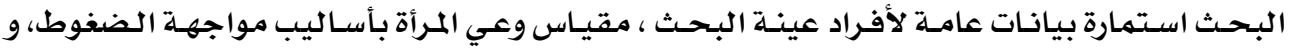

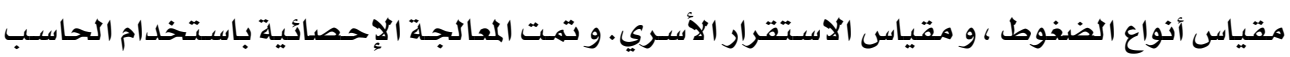

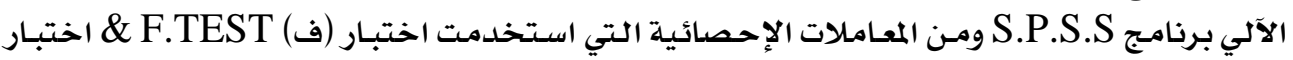

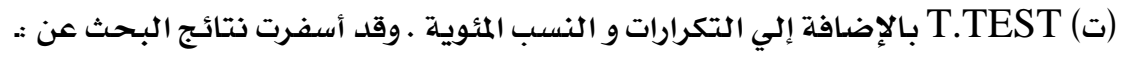

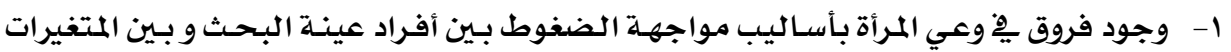

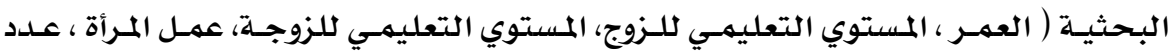

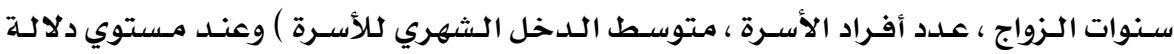
. (•, $(\cdot)$

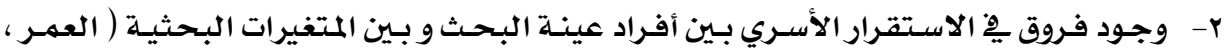

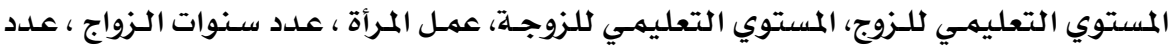

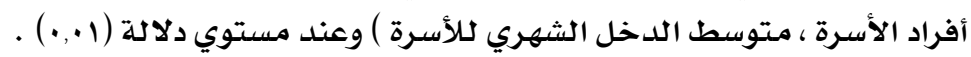

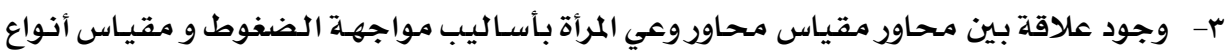

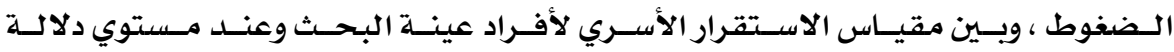

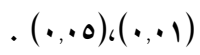

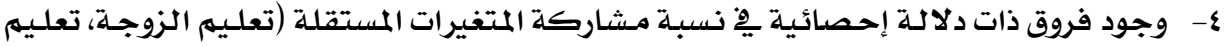

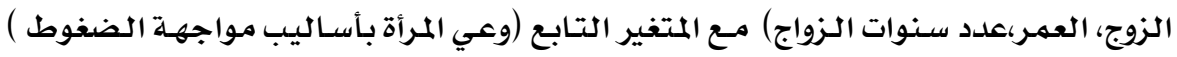

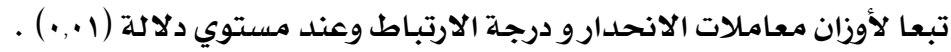

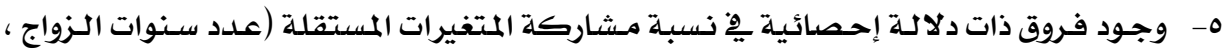

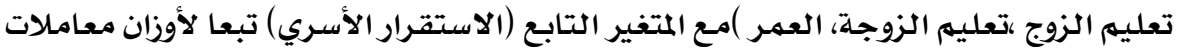

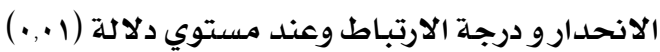

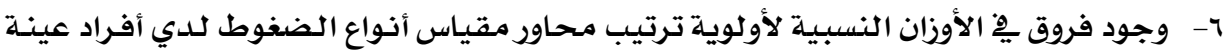
البحثث . 1 أبود 


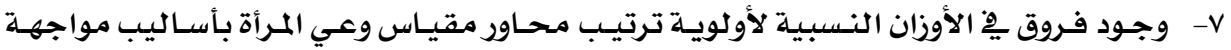

$$
\text { الضغوط لدي أفراد عينة البحث . }
$$

و توصي الباحثة بضرورة إعداد البر امـج الارثاديه ضمن تخصص قسمه إدارة مؤسسات الأسرة

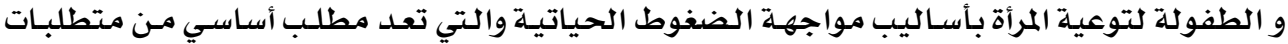

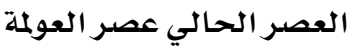


Women's awareness of ways the face of pressure and its relationship to family stability

Dr. Naglaa Sayed Hussein •

\section{Abstract:}

This research aims to reveal the relationship between women's awareness of ways the face of pressure and family stability, and the research was conducted on a sample of female heads of households and the strength of the (285) heads of household and economic levels and different social., And follow in the search descriptive analytical method, and use the search form data General members of the research sample, measure the awareness of women in the face of pressures ways, and the kinds of pressure scale, and the scale of family stability. And has statistical processing CNC program SPSS statistical and transactions of used test (P) F.TEST \& test (T) T.TEST, in addition to the frequencies and percentages. The results Search for:

1- The existence of differences in women's awareness of ways the face of pressures between members of the research sample and between variables research (age, educational level of the husband, the educational level of the wife, women's work, number of years married, number of family members, the average monthly income of the family) and at the level of significance $(0,01)$.

2-There are differences in family stability among the members of the research sample and between variables research (age, educational level of the husband, the educational level of the wife, women's work, number of years married, number of family members, the average monthly income of the family) and at the level of significance $(0,01)$.

3-The existence of a relationship between axes axes measure the awareness of women in the face of pressure and ways kinds of pressure gauge, and the measure of family stability for members of the research sample and at the level of significance $(0,01),(0,05)$.

\footnotetext{
"Assistant Professor of Management of Family Institutions and Childhood Department Faculty of Home Economics - Helwan University
} 
4-There were statistically significant differences in the proportion of post independent variables (education wife, spouse education, age, number of years of marriage) with the dependent variable (the awareness of women in the face of pressures ways) depending on the weights of the regression coefficients and the degree of correlation and at the level of significance (0.01) .

5-There were statistically significant differences in the rate of participation of independent variables (the number of years of marriage, education husband, wife's education, age) with the dependent variable (family stability) depending on the weights of the regression coefficients and the degree of correlation and at the level of significance (0.01) .

6-There are differences in the relative weights of the order of priority axes scale kinds of pressure I have members of the research sample .

7-There are differences in the relative weights of the order of priority axes measure the awareness of women in the face of pressure I have ways members of the research sample .

The researcher recommends the need to set up outreach programs within the specialty management department of family and childhood institutions to educate women in ways that face the pressures of life, which is an essential requirement of the requirements of the current era of globalization era . 


\section{وعي المرأة بأساليب هواجهة الضغوط و علاقته بالاستقرار الأسري \\ إعداد}

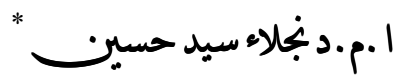

مقدمهة و مشكلة البصث

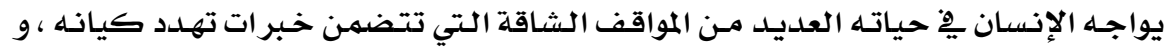

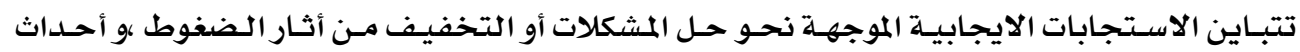

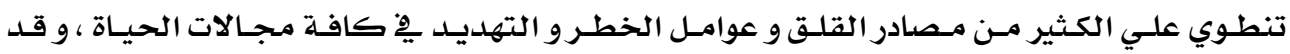

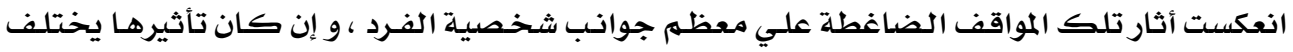

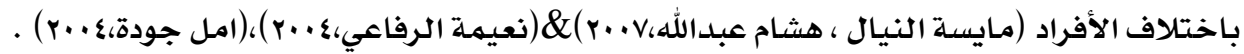

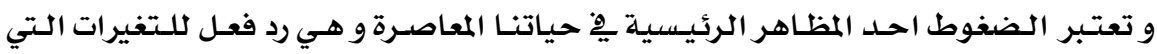

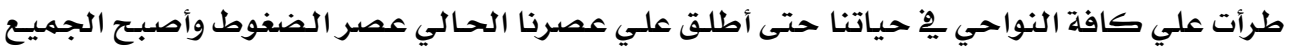

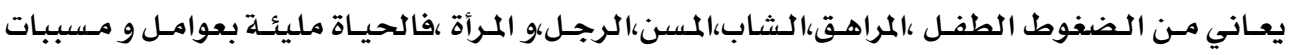

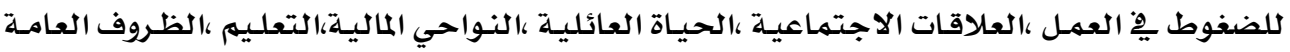

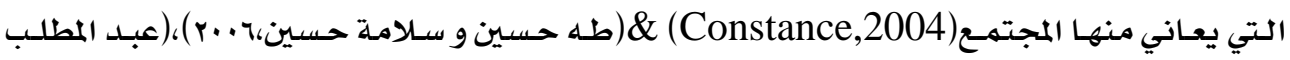

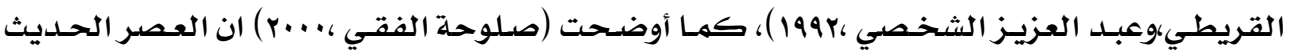

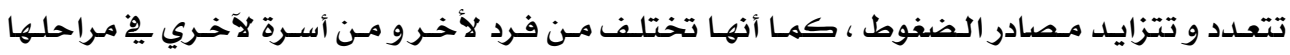

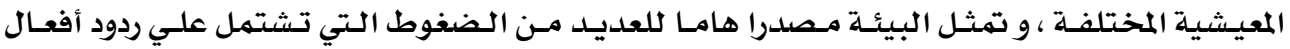

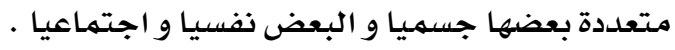

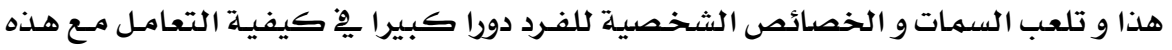

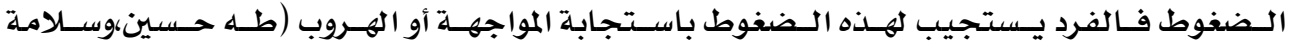

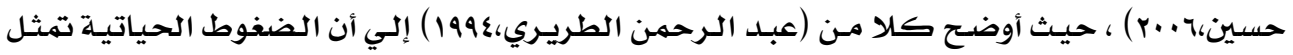

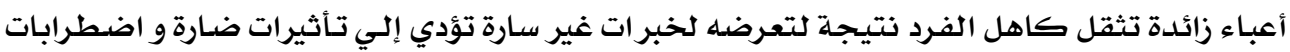

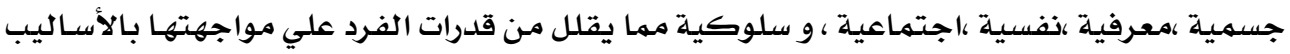

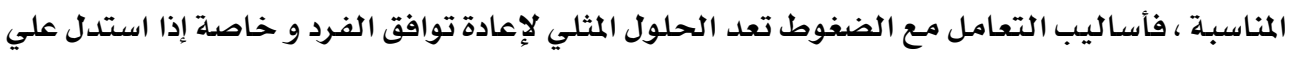

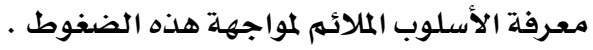

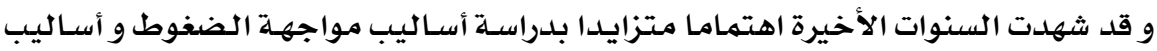

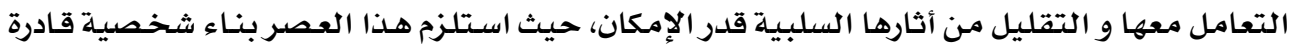

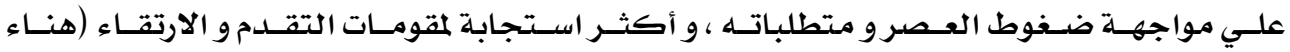




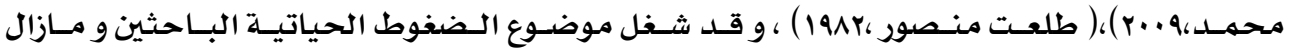

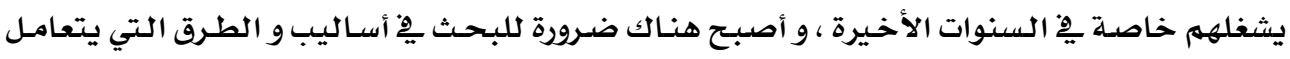

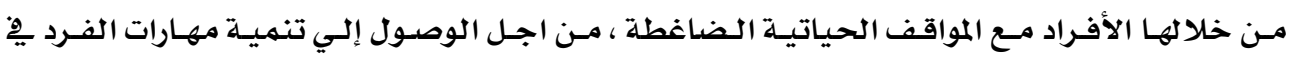

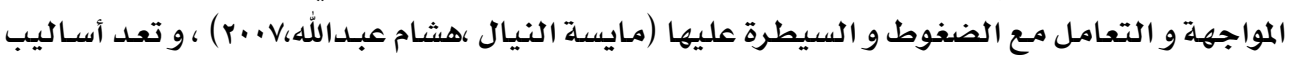

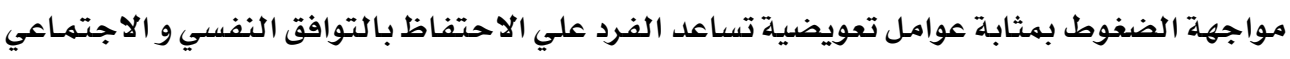

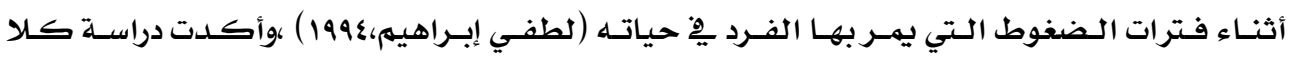

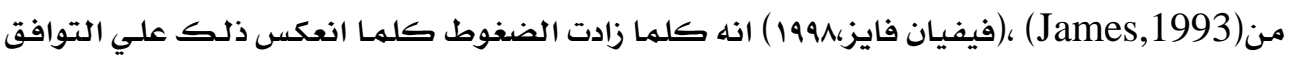

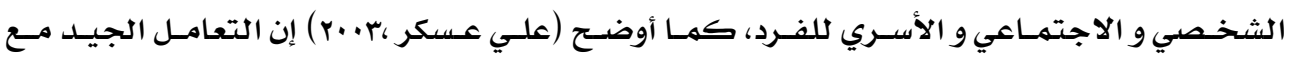

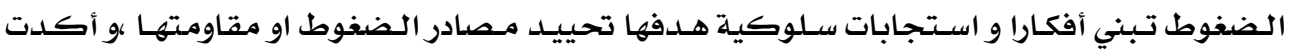

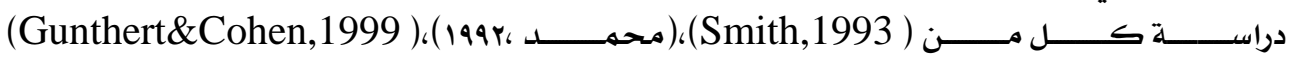
علسي أن تعلـم و اكتساب و إتقـان بعض الأسـاليب و الطرق التي تساعد (Rothrock,et.al,2003)،

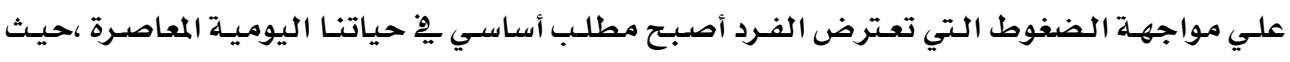

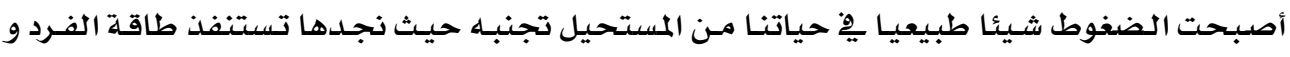

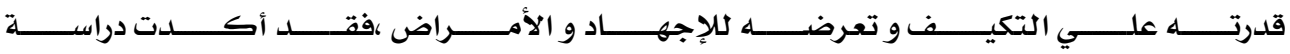
(Kobssa,S\&Puccet,M,1983)

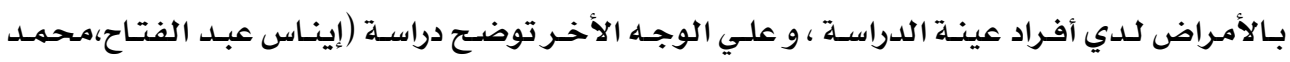

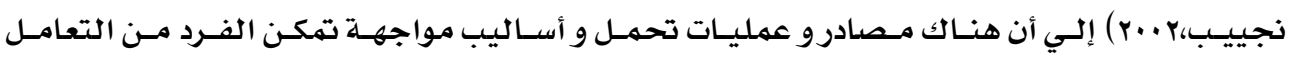

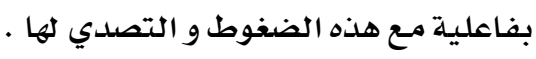
وتتعرض المرأة يِّ جميع مـراحل حياتها إلي مواقف و ضغوط و مؤشـرات شـديدة مـن مصـادر

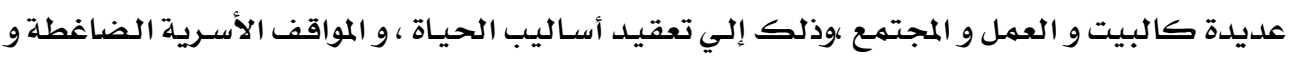

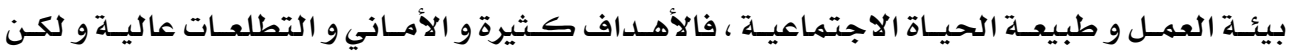

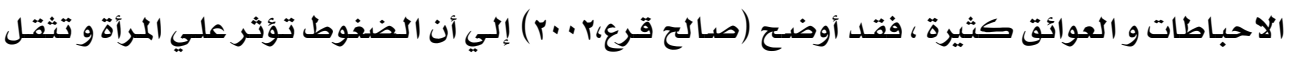

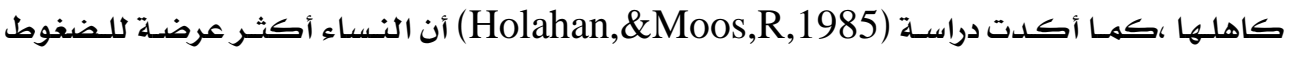

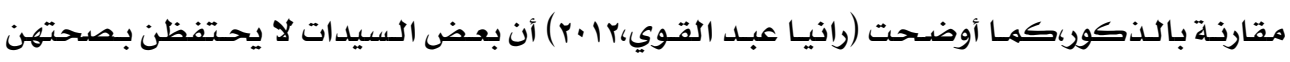

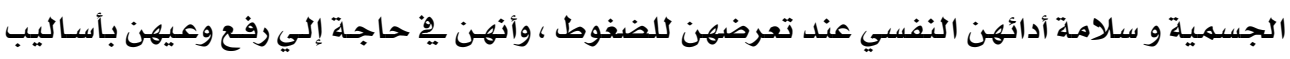

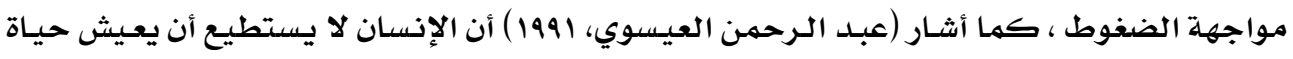

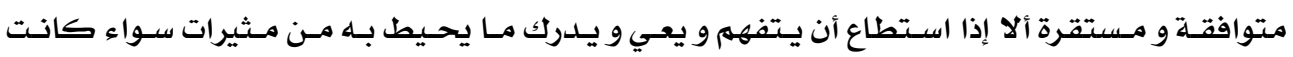

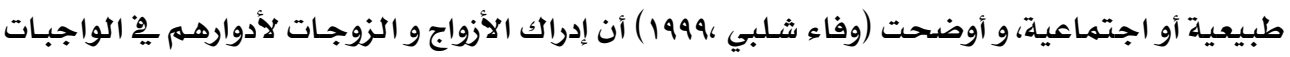

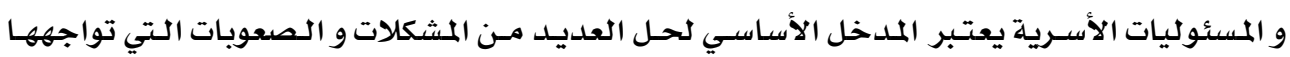

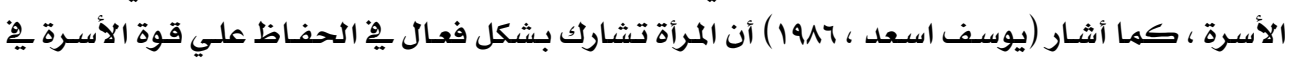

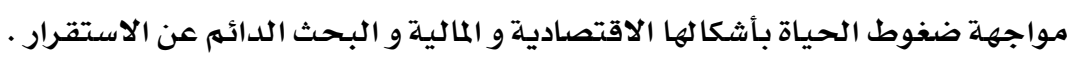

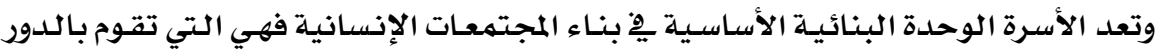

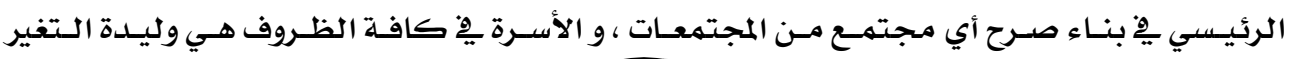




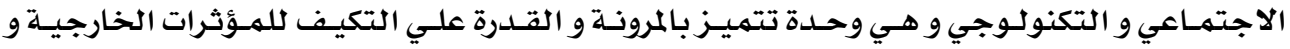

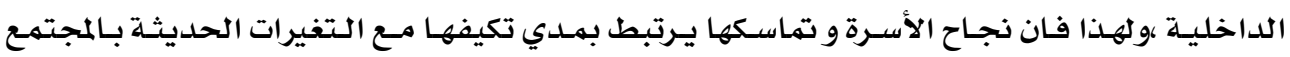

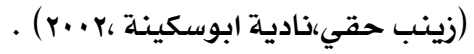

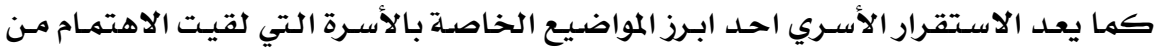

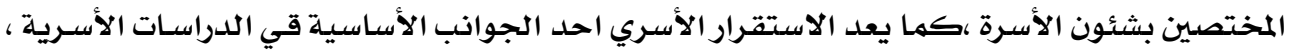

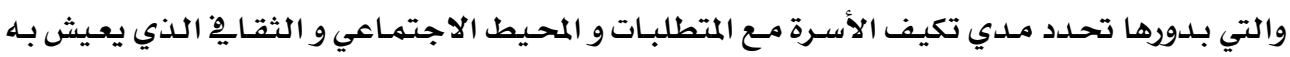

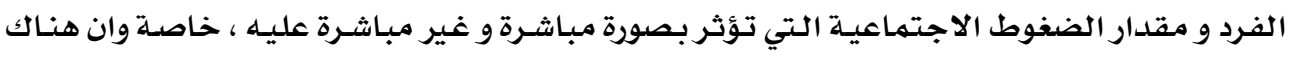

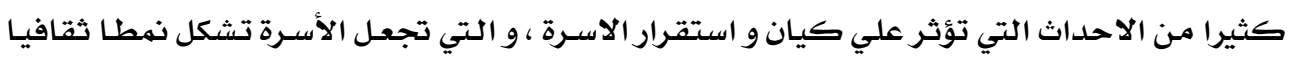

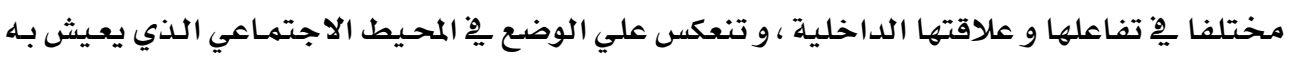

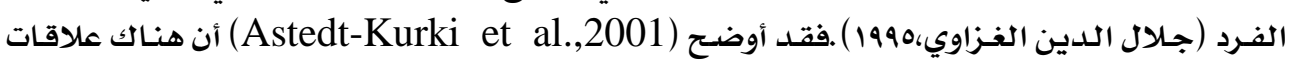

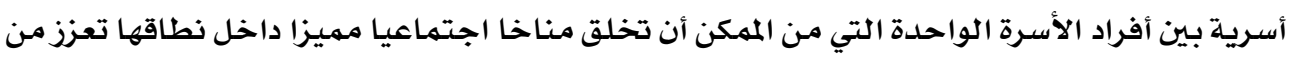

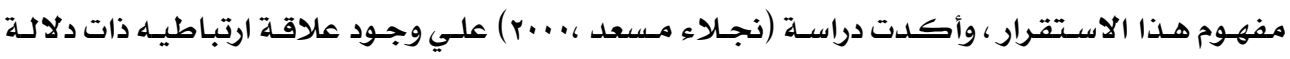

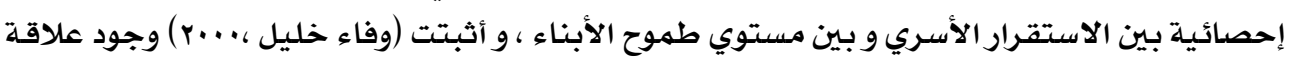

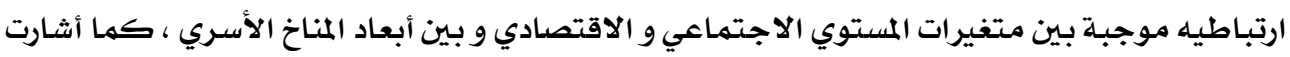

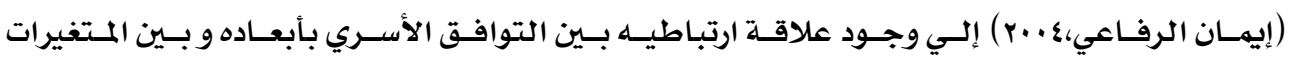

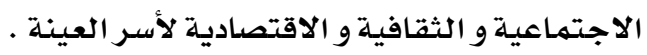

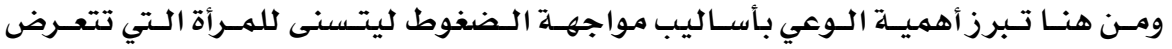

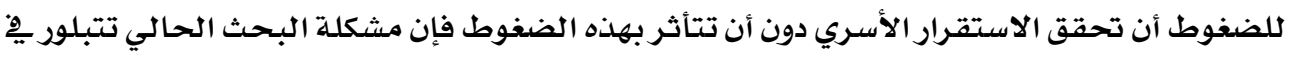

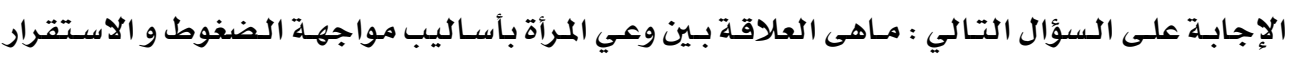

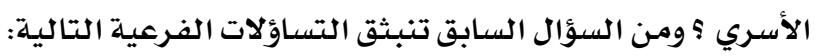

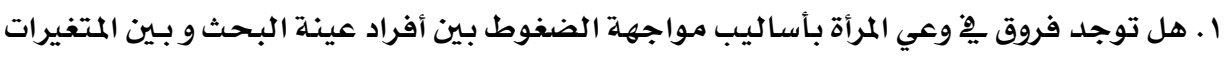

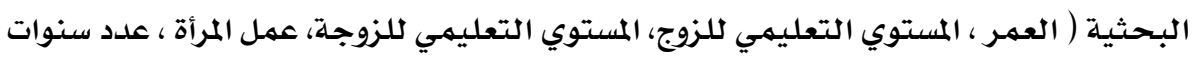

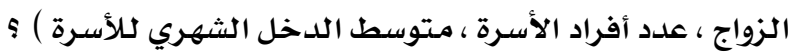

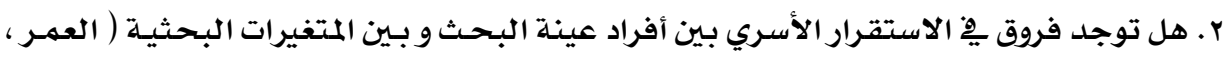

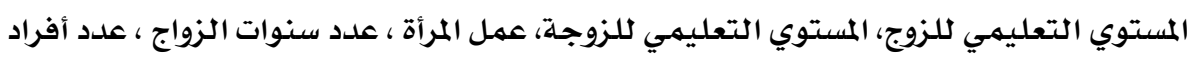

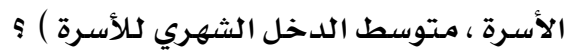

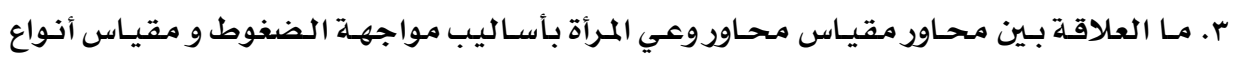

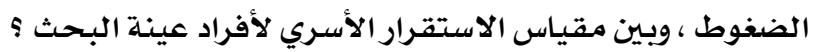

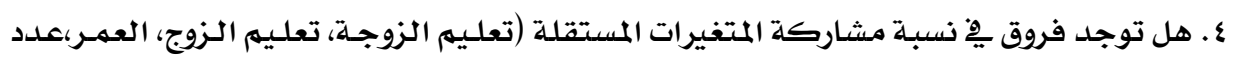

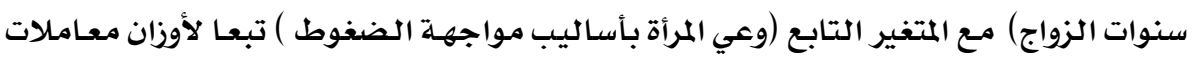

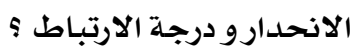




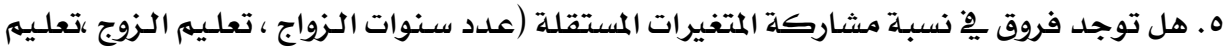

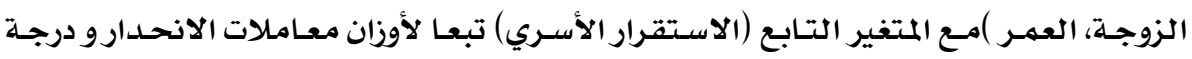

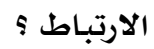

T. ماهي الأوزان النسبية لأولوية ترتيب محاور مقياس أنواع الضغوط لدي أفراد عينة البحث ؟

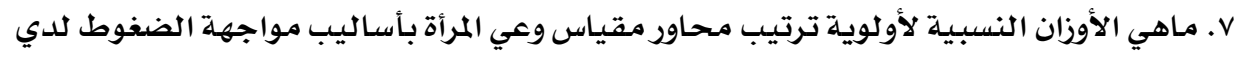
أفراد عينة البحث ؟ ماهي الان النسئ

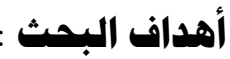

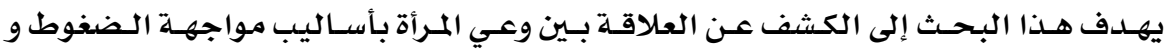

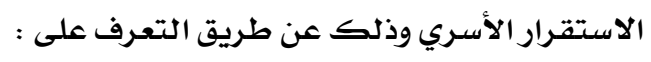

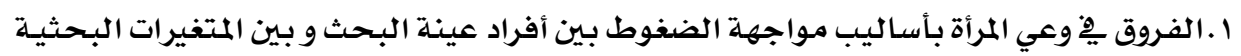

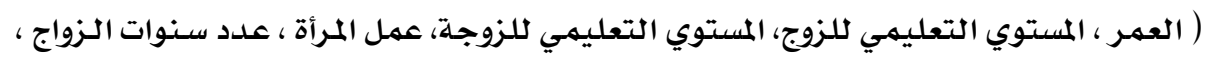

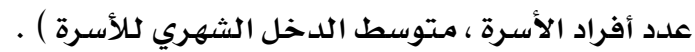

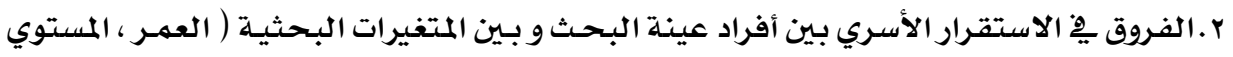

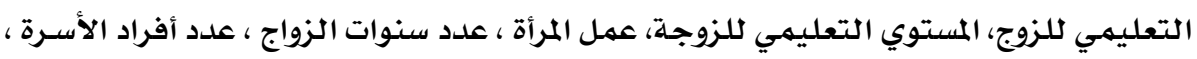

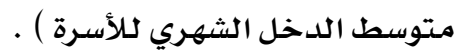

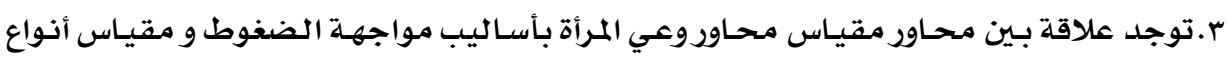

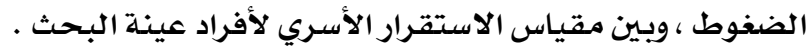

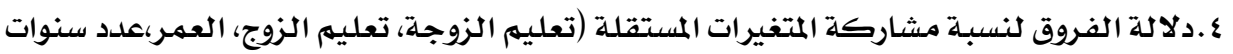

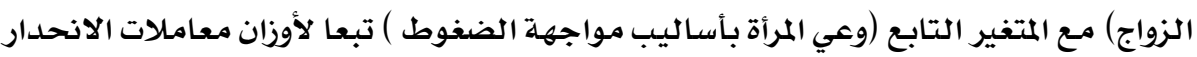

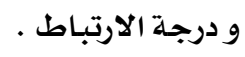

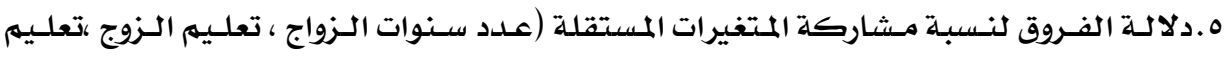

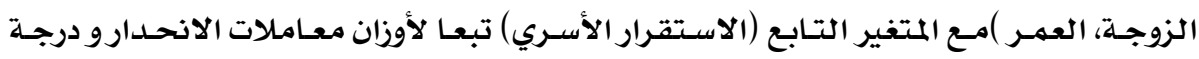

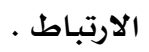

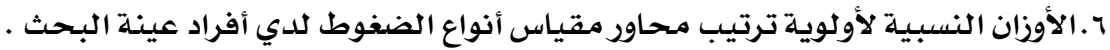

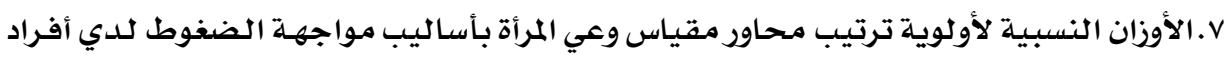
عينة البحثث . تتمثل أهمية البحث فيما يلي :

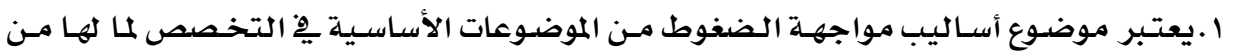

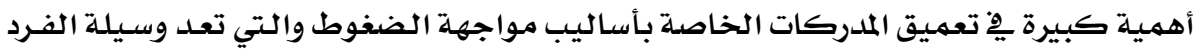

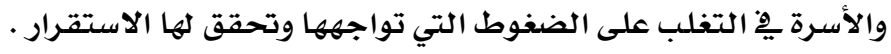




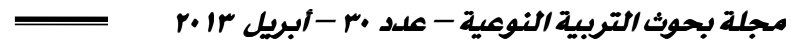

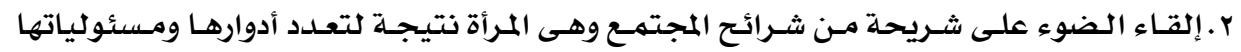

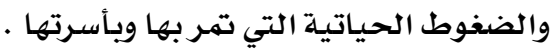

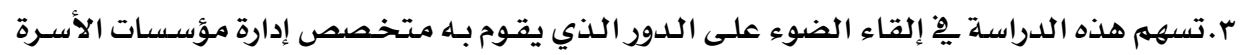

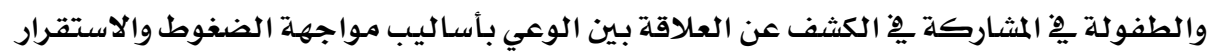
الأسـرى.

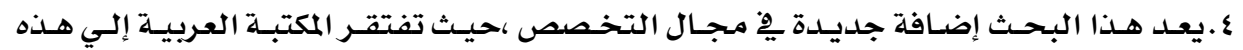

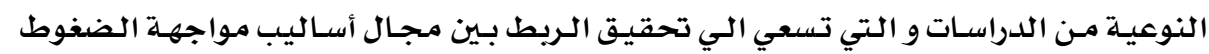

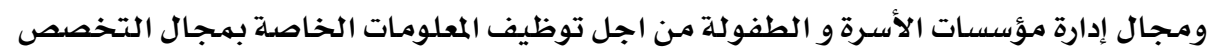

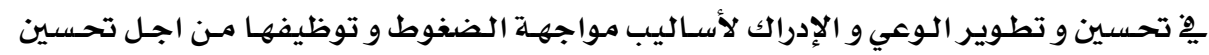

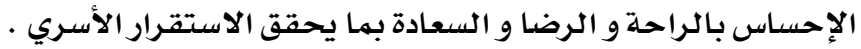

$$
\text { يفترض البحث الفروض التالية: }
$$

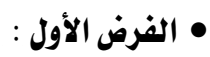

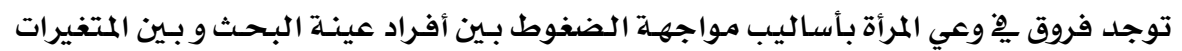

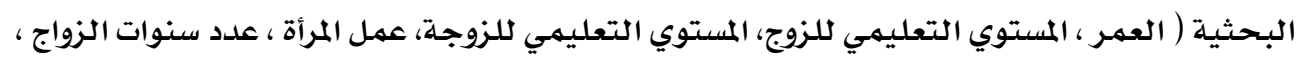

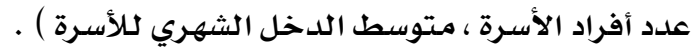

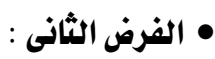

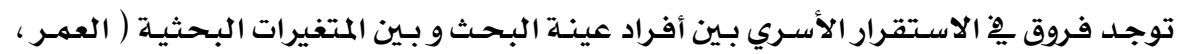

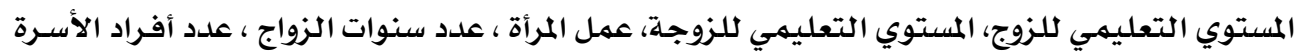
، متوسط الدخل الثهري لكلأسرة ) . • الفرض الثالث : متوسط الدخل

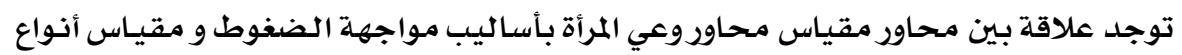

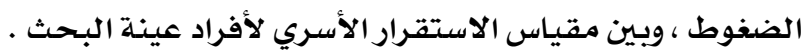

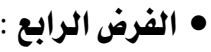

تختلف الفروق لنسبة مشاركة المتغيرات المستقلة (تعليم الزوجـة، تعليم الزوج، العمـر،عدد المداد

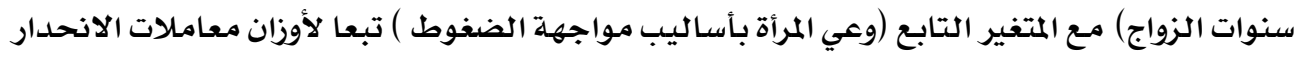
و درجة الارتباط .

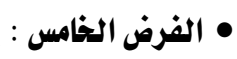

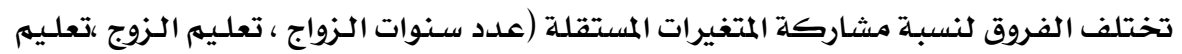

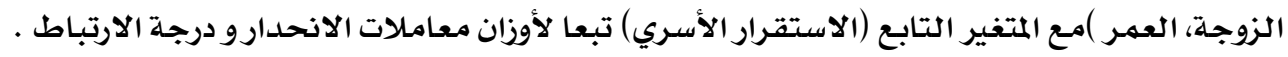




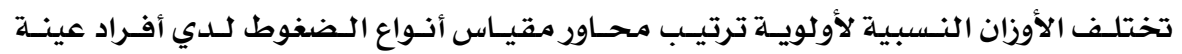

البحث.

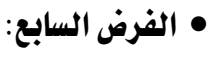

تختلف الأوزان النسبية لأولوية ترتيب محاور مقياس وعي المرأة بأسـاليب مواجهة الضغوط

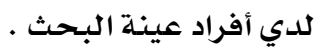

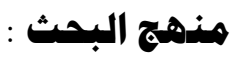

يتبـع هذا البحث المنهج الوصفي التحليلي و يقصد بالمنهج الوصفي الذي يقوم علي الدراسـة

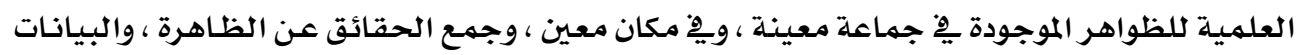

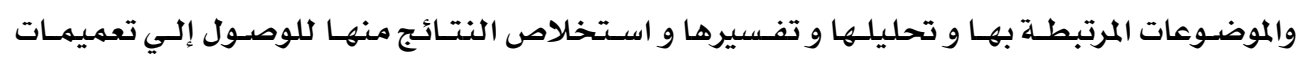

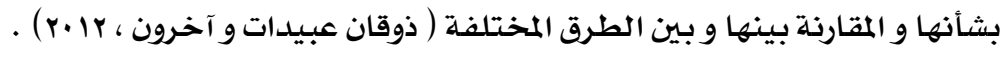
هدود البحث :

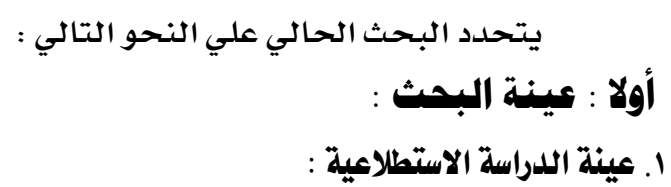

تم إجراء اختبار مبدئي Pre-Test لأدوات البحث، بتوزيعها علسي عينـة استطلاعيـة اختيـرت

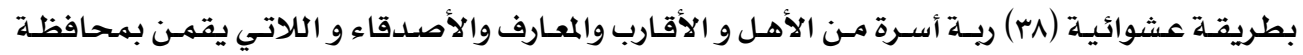

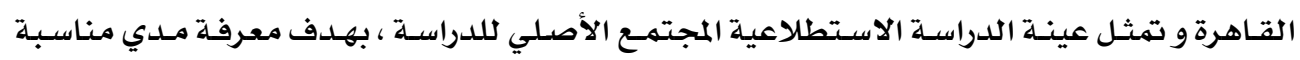

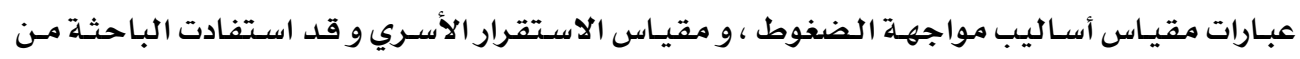

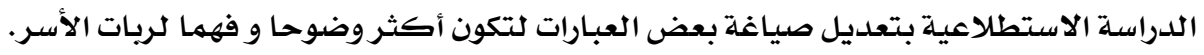

\section{r. عينة البحث الأساسية:}

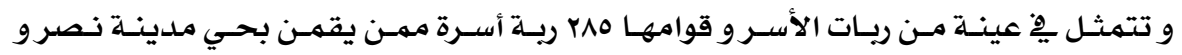

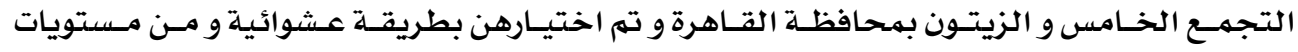

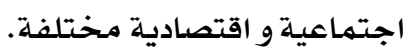

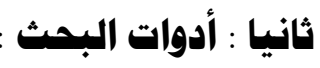

$$
\text { اشتملت أدوات البحث علي ما يلي : }
$$

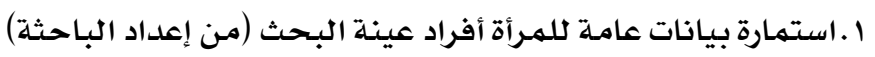

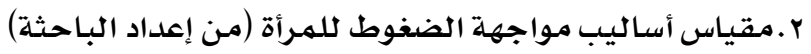

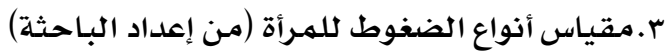

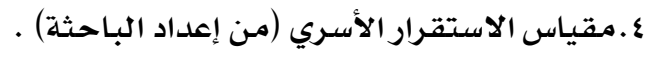




\section{خطوات إجراء البحث}

$$
\text { قامت الباحثة بالخطوات التالية لإجراء البحث : }
$$

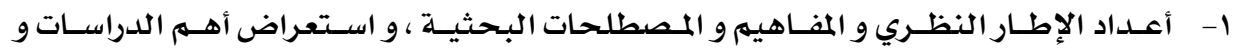

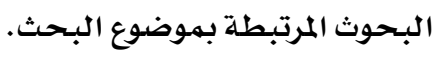

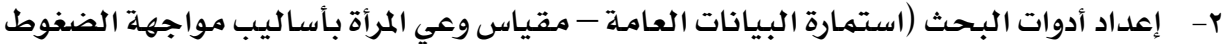

$$
\text { - أنواع الضغوط للمرأة -مقياس الاستقرار الأسري). }
$$

r- - عرض أدوات البحث علي العينة الاستطلاعية لتقنين الاستبيان.

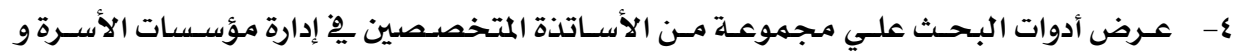

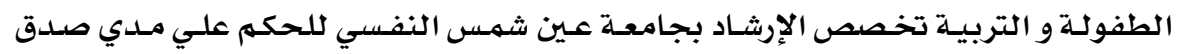

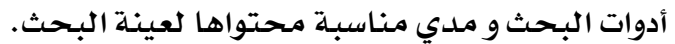

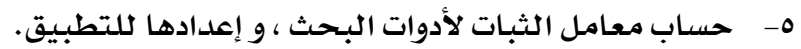

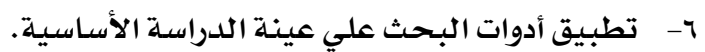

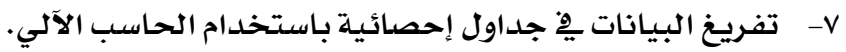

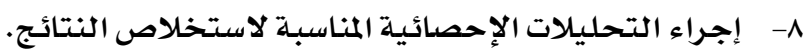

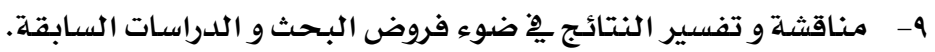
1. أستخلاص التوصيات و المقترحات.

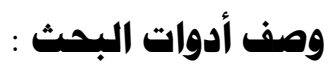

اشتملت أدوات البحث الحالية علي أربعة أدوات هي :

أولا : استمارة البيانات العامة لعينة البحثُ (إعلاد الباحثة) :

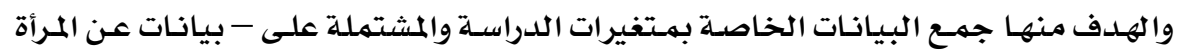

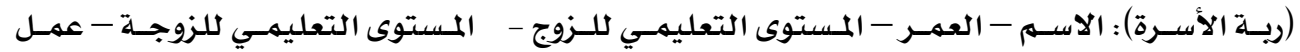

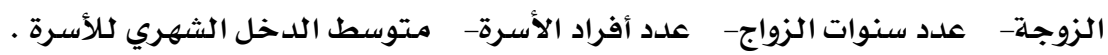

\section{ثانيا : مقياس أنواع الضفوط :}

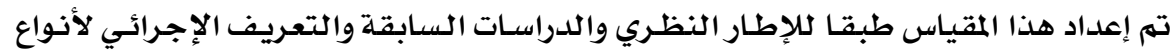

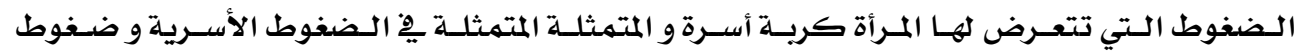

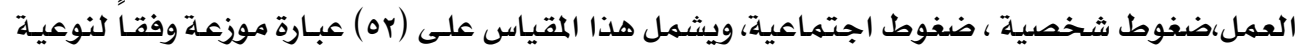

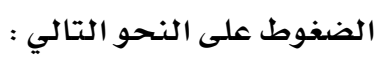

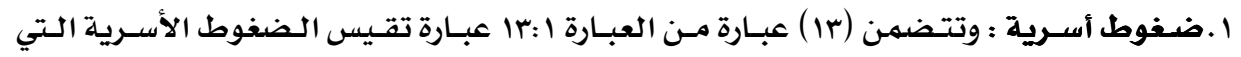

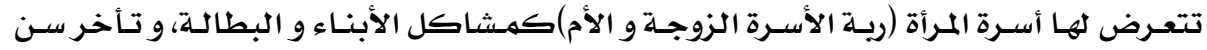

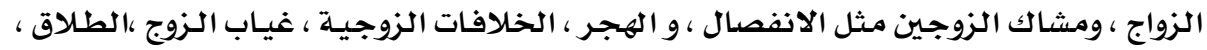


عدم عمل الزوج ،مرض احد أفراد الأسرة ، ارتفاع الأسعار المستهمروغيرها من الضغوط الأسـرية

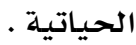

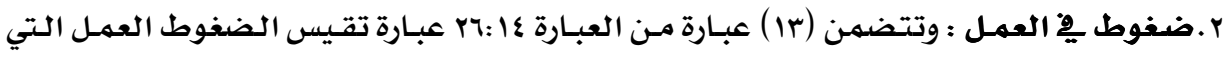

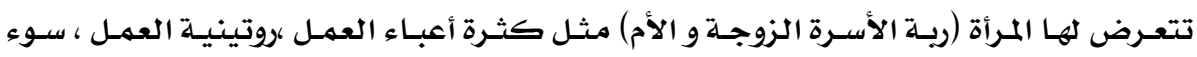

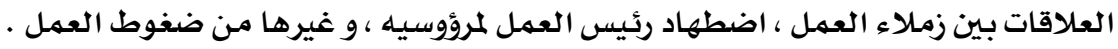

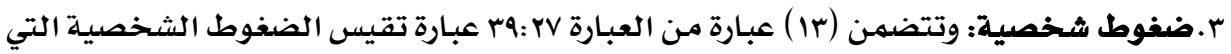

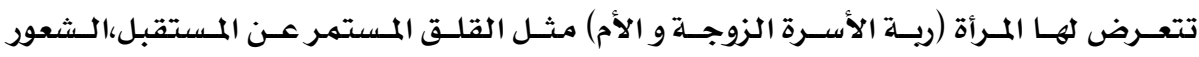

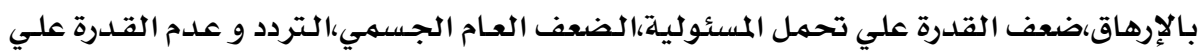

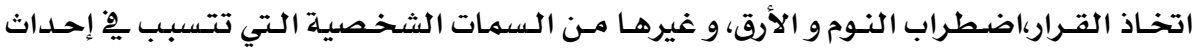

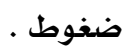

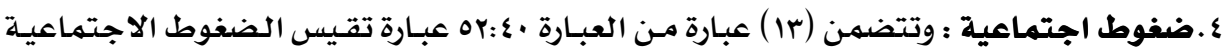

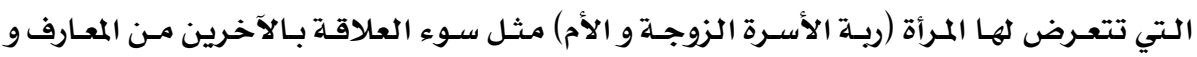

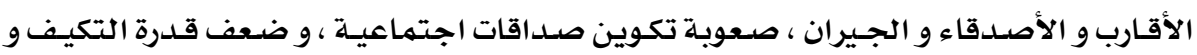

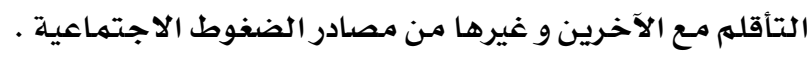

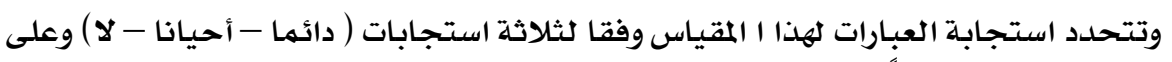

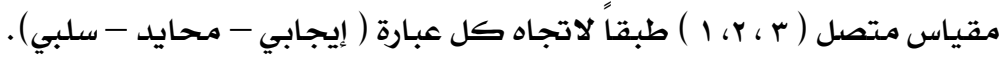
ثالثا : مقياس أساليب مواجهة الضفوط مئمة تم إعداد هذا المقياس طبقا للإطار النظري والدراسات السابقة والتعريف الإجرائي لأساليب

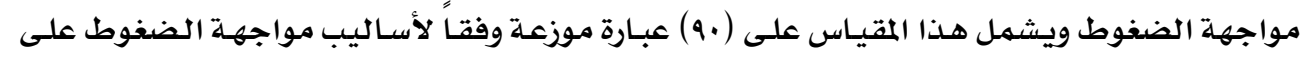

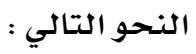

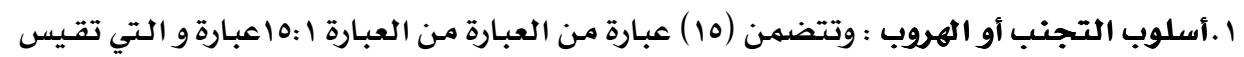

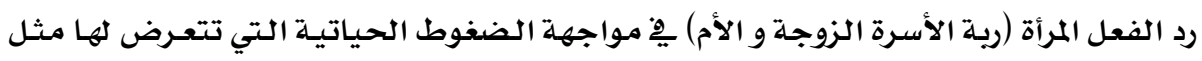

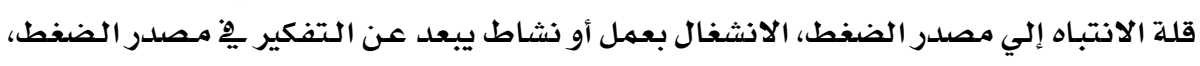

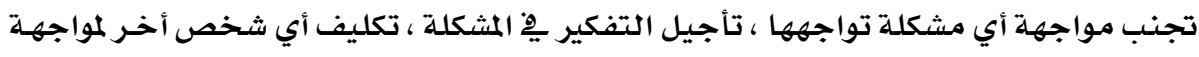

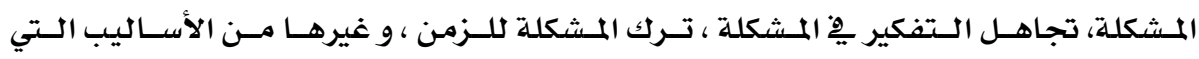

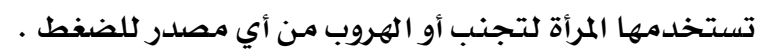

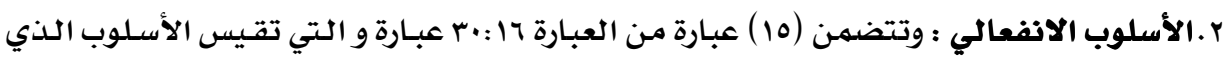

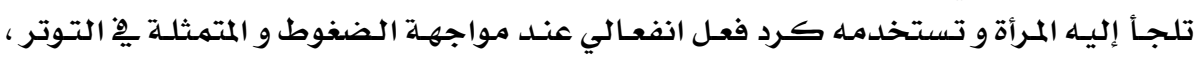

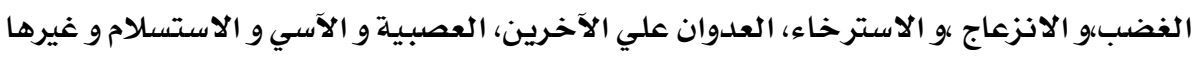

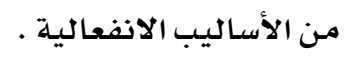

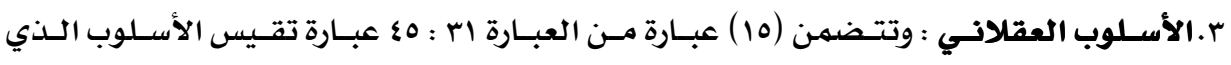

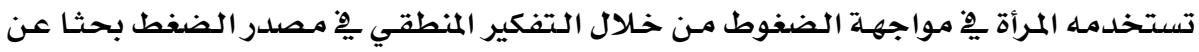




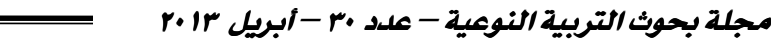

مصادر القلق و أسبابه المرتبطة بالضغوط و مناقشة المشكلة بموضوعية ، استشارة أهل الخبرة ،

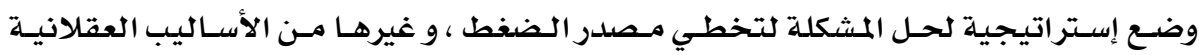

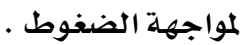

ع . أسلوب المساندة الاجتماعية : وتتضمن (10) عبارة 7؟ : . 7عبـارة تقيس مـدي مساندة المحسيطين

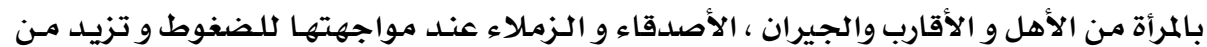

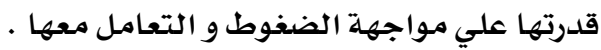

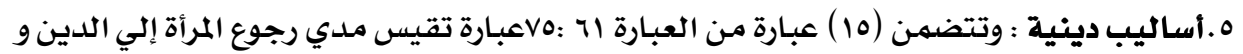

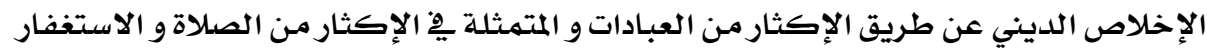

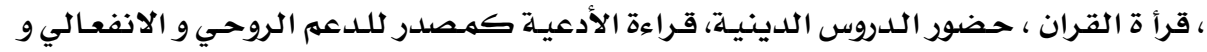

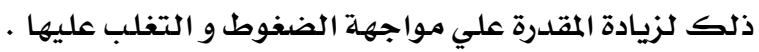

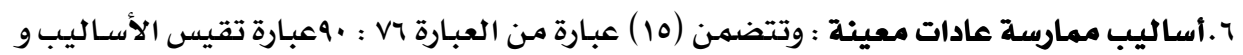

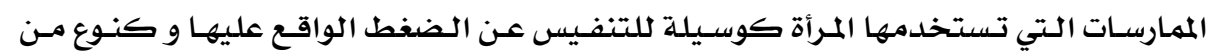

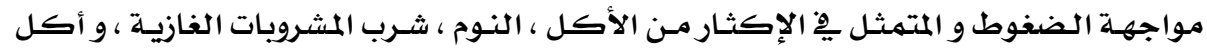

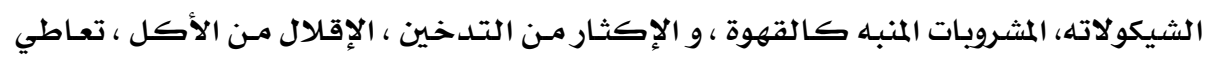

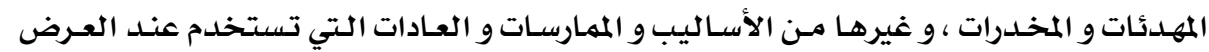
للضغوط المعات وتتحدد استجابة العبارات لهذا المقياس وفقا لثلاثة استجابات ( دائما - أحيانا - لا ) وعلى ) ولى

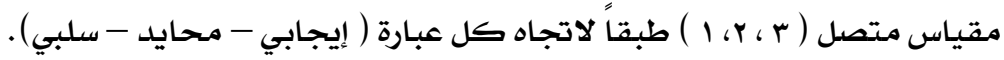
رابعا : مقياس الاستقرار الأسري :

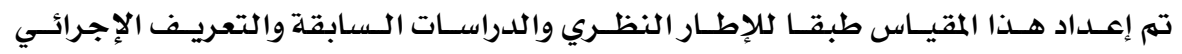

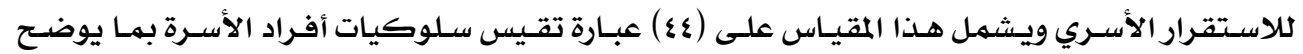

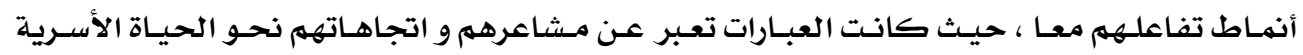

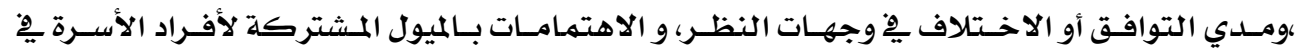

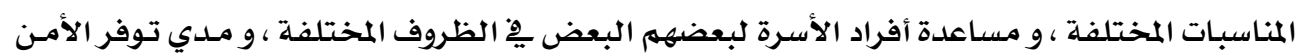

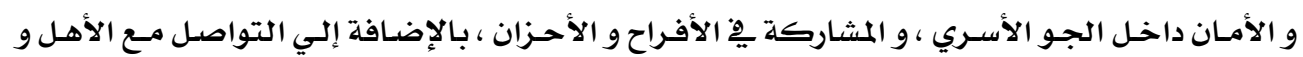

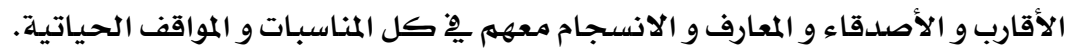

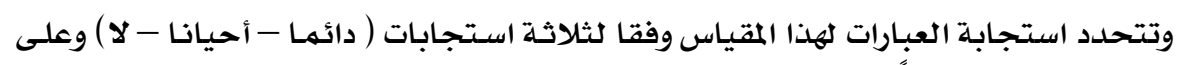

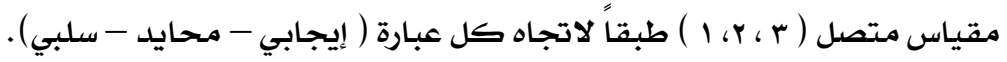

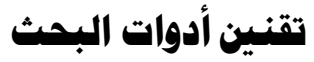
صدق المحكميز : وقد استخدمت الباحثتان الطرق الآتية : 


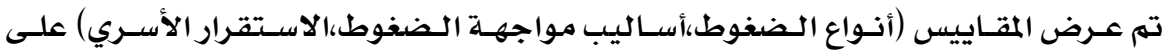

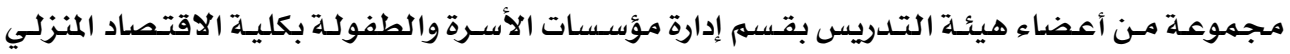

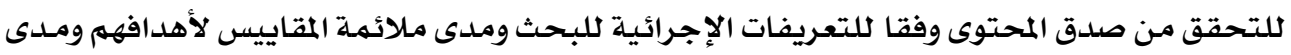

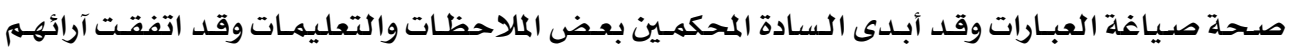

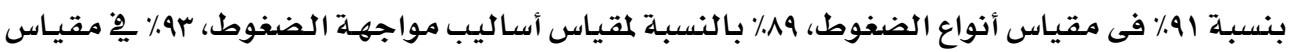
الاستقرار الأسـري.

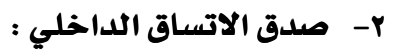
وذلك عن طريق إيجاد معاملات الارتباط باستخدام معامل بيرسون : أ- حسـاب معامل الارتباط بين درجة كل عبارة من عبـارات كل محسورو الدرجـة الكليـة للمحسور وكانت جميعها دالة عند مستوي دلالة (1 (-.).

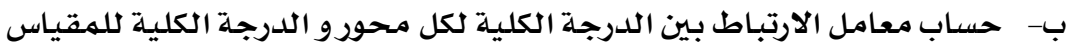

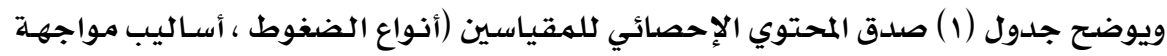

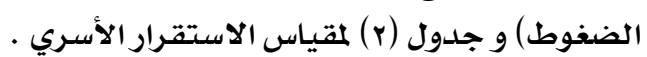
جدول (1) صدق المحتوي الإحصائي لمقياس أنواع الضغوط ، أساليب مواجهة الضغوط

\begin{tabular}{|c|c|c|}
\hline 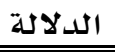 & الارتباط & مححاور أنواع الضغوط \\
\hline$\cdot, \cdot 1$ & $\cdot, \mathrm{VY \Lambda}$ & المحور الأول : ضغوط أسريـة \\
\hline$\cdot, \cdot 1$ & $\cdot 91 \mathrm{r}$ & المحور الثانى : ضغوط ِِِ العمل \\
\hline$\cdot, \cdot 1$ & $\cdot, \mathrm{\vee} \wedge \mathrm{Q}$ & المحور الثالث : ضغوط شخصية \\
\hline$\cdot . \cdot 1$ & $\cdot, \wedge \cdot 9$ & المحور الرابع : ضغوط اجتماعية \\
\hline 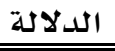 & الارتباط & \\
\hline$\cdot, \cdot 1$ & $\cdot$ • AYo & المحور الأول : أسلوب التجنب أو الهروب \\
\hline$\cdot, \cdot 1$ & $\cdot, \wedge \Lambda \varepsilon$ & المحور الثاني : الأسلوب الانفعالي \\
\hline$\cdot, \cdot 1$ & $\cdot, \times 19$ & المحور الثالث : الأسلوب العقلانى \\
\hline$\cdot, \cdot 1$ & $\cdot, 9 \cdot \mathrm{V}$ & المحور الرابع : أسلوب المسـاندة الاجتماعيلة \\
\hline$\cdot, \cdot 1$ & $\cdot, \mathrm{VVV}$ & المحور الخامس : أسـاليب دينيـة \\
\hline$\cdot, \cdot 1$ & $\cdot$, , $0 \mathrm{~V}$ & المحور السـادس : أساليب ممـارسـة عادات معينـة \\
\hline
\end{tabular}

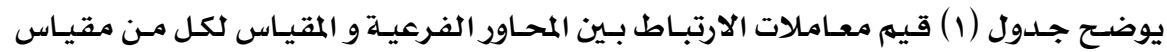

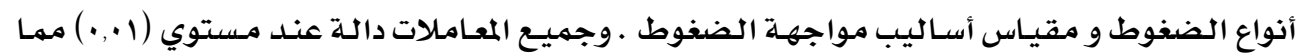
يؤكد الصدق العاملي. 


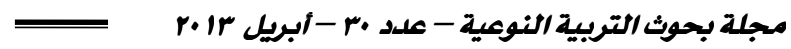

جدول (r) معاملات الارتباط بين درجة كل عبارة و الدرجة الكلية للمقياس

\begin{tabular}{|c|c|c|c|c|c|}
\hline الدلالة & الارتباط & P & الدلالة & الارتباط & $\hat{\imath}$ \\
\hline$\cdot, \cdot 1$ & $\cdot, \lambda \cdot 1$ & rr & $\cdot, \cdot 1$ & •, V६• & -1 \\
\hline$\cdot, \cdot 1$ & •, & $-Y \xi$ & $\cdot, \cdot 1$ & $\cdot, \wedge 01$ & $-r$ \\
\hline$\cdot, \cdot 1$ & , $\mathrm{Y79}$ & -ro & $\cdot, \cdot 1$ & $\cdot, \mathrm{AAI}$ & $-r$ \\
\hline$\bullet, \cdot 1$ & •, А७ & -ry & $\bullet, .0$ & rוד, & $\varepsilon$ \\
\hline$\cdot, \cdot 1$ & $\cdot, \wedge 91$ & - rV & $\cdot, \cdot 1$ & •, $\Delta r \wedge$ & -0 \\
\hline$\cdot, \cdot 1$ & , Yo1 & $-r \Lambda$ & $\cdot, \cdot 1$ & $\cdot, r+1$ & -7 \\
\hline$\cdot, \cdot 1$ & •,वस\& & - & $\cdot, \cdot 1$ & •, $\mathrm{\vee 9A}$ & $-r$ \\
\hline$\cdot, \cdot 1$ & 只 & - r. & $\cdot, \cdot 1$ & •, qro & $-\Lambda$ \\
\hline$\cdot, \cdot 0$ & $\cdot, 7 \cdot 1$ & - II & $\cdot, \cdot 1$ & $\cdot, 901$ & -9 \\
\hline$\cdot, \cdot 1$ & •,ATY & rr & $\cdot, \cdot 0$ & 政 & -1. \\
\hline$\cdot, \cdot 1$ & •, Avo & rr & $\cdot, \cdot 0$ & 政 & -11 \\
\hline$\cdot, \cdot 1$ & •, VT\& & E & $\cdot, \cdot 1$ & •, १६४ & $-1 T$ \\
\hline$\cdot, \cdot 1$ & •, q1Y & .ro & $\cdot, \cdot 1$ & • VIr & זו- \\
\hline$\cdot, \cdot 1$ & •, ४৭६ & I & $\cdot, \cdot 1$ & •, 199 & -18 \\
\hline$\cdot, \cdot 1$ & $\cdot, \wedge \wedge \wedge$ & -rV & $\cdot, \cdot 1$ & •, qr. & -10 \\
\hline$\cdot, \cdot 1$ & $\cdot, v \cdot \Lambda$ & ה & $\cdot, \cdot 1$ & •, YrI & -17 \\
\hline$\cdot, \cdot 1$ & •, $\wedge \varepsilon 0$ & . & $\cdot, \cdot 0$ & $\cdot, 7 \cdot 1$ & -IV \\
\hline$\cdot, \cdot 1$ & $\cdot, 9.1$ & كـ & $\cdot, \cdot 1$ & •,AlY & -11 \\
\hline$\cdot, \cdot 1$ & $\cdot, 9 Y \wedge$ & اكـ & $\cdot, \cdot 1$ & •,АТ & -19 \\
\hline$\cdot, \cdot 0$ & $\cdot, 7 r A$ & L & $\cdot,+1$ & •,AVq & $-r \cdot$ \\
\hline$\cdot, \cdot 1$ & •, व\&r & . & $\cdot, \cdot 1$ & •, rrq & $-r$ \\
\hline$\cdot, 0$ & •, $1 \xi 1$ & . $\{\xi$ & $\cdot, \cdot 1$ & $\cdot, \wedge \leqslant 9$ & $-r r$ \\
\hline
\end{tabular}

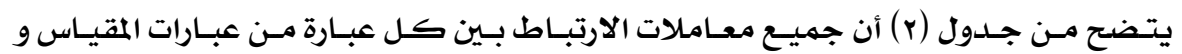

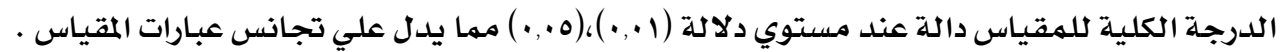

ثبات المقاييس:

تم تحديد معامل الثبات بأربعة طرق هي :

1- الفاكرونباخ Alpha Gronbach لتحديد قيمة الاتساق الداخلي .

r

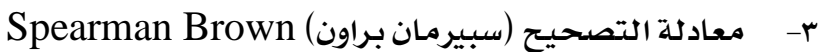




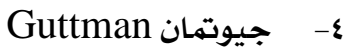

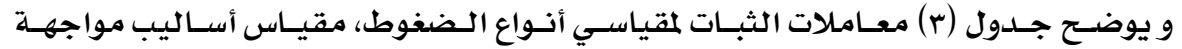

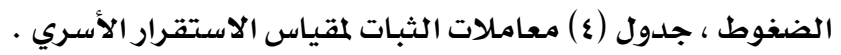

جدول(r) معاملات الثبات لمقياسي أنواع الضغوط، أساليب مواجهة الضغوط

\begin{tabular}{|c|c|c|c|c|}
\hline جيوتثان & سبيرمان براون & التجزئة النصفية & معامل الفا & 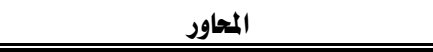 \\
\hline$\cdot, 9 \cdots$ & $\cdot, 90$. & •, Avo & •, q14 & المحور الأول : ضفوط أسرية \\
\hline$\cdot$, rrA & $\cdot, \mathrm{\vee} \wedge 0$ & $\cdot, v \cdot 1$ & $\cdot, v \leqslant 1$ & المحور الثاني : ضفوط في العمل \\
\hline$\cdot, 79 \cdot$ & $\cdot, \mathrm{v} \varepsilon \mathrm{q}$ & •, ITV & $\cdot, \mathrm{r} \cdot \mathrm{A}$ & المحور الثالث : ضفوط شخصية \\
\hline •, YYA & •,AT\& & •, ror & •, $\mathrm{\vee q \xi}$ & المحور الرابع : ضفوط اجتماعية \\
\hline$\cdot$, Arr & $•, 9 r \mathrm{r}$ & $\cdot$, A01 & $\cdot, \wedge 9 \xi$ & ثبات الاستبيان ككل \\
\hline جيوتثان & سبيرمان براون & التجزئة النصفية & معامل الفا & المحاور - الم \\
\hline$\cdot, \mathrm{vOl}$ & $\cdot, \Lambda \cdot 7$ & •, rro & $\cdot, \vee \vee \wedge$ & المحور الأول : أسلوب التجنب أو الهروب \\
\hline , vq. & $\cdot, \wedge \varepsilon Y$ & $\cdot, \vee \vee 1$ & $\cdot, \wedge \cdot \eta$ & المحور الثاني : الأسلوب الانفعالي \\
\hline$\cdot$, var & • Alr & $\cdot$, vrr & $\cdot, r \vee \vee$ & المحور الثالث : الأسلوب العقلاني \\
\hline • vir & $\cdot, \mathrm{V} 4 \mathrm{~A}$ & $\cdot, 791$ & •, Vrq & المحور الرابع : أسلوب المساندة الاجتماعية \\
\hline$\cdot$, AVr & •, बrr & $\cdot, \wedge \varepsilon \cdot$ & $\cdot, \wedge \wedge 1$ & المحور الخامس : أساليب دينية \\
\hline$\cdot$, AAV & $\cdot, 9 \leqslant Y$ & •, גit & $\cdot, 9 \cdot v$ & المحور السادس : أساليب ممارسة عادات معينة \\
\hline$\cdot, \wedge \leqslant Y$ & $\cdot, 9 \cdot 1$ & $\cdot$, AYr & $\cdot, 199$ & ثبات الاستبيان ككل \\
\hline
\end{tabular}

يتضح من جدول (r) أن معاملات الثبات لمقياسي أنواع الضغوط ، أساليب مواجهة الضغوط كانت مرتفعة مما يسهـح باستخدام هذين المقياسين يِّ البحثث . جدول(ع) معاملات الثبات لمقياس الاستقرار الأسري

\begin{tabular}{|c|c|c|c|c|}
\hline جيوتمان & سبيرمان براوز & التجزئة النصفية & معامل الفا & \\
\hline •, Alr & $\cdot, \wedge 7$. & •, VAr & •,Arr & ثبات الاستبيان ككل \\
\hline
\end{tabular}

يتــح مـن جـدول (ع ) أن معـاملات الثبـات لمقيـاس الاسـتقرار الأسـري كانـت مـرتفعـة مهـا

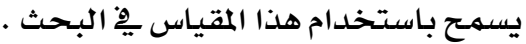

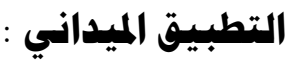

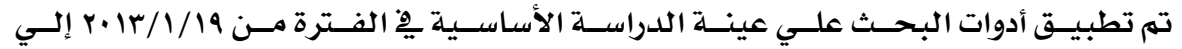

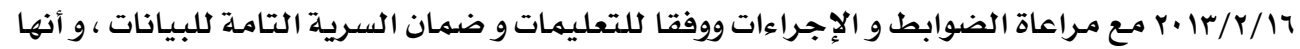

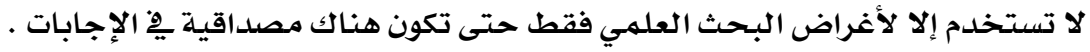




\section{إجراءات التصليلات الإحصائية :}

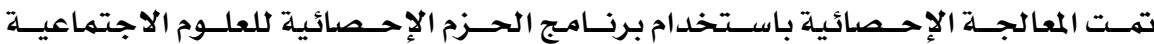

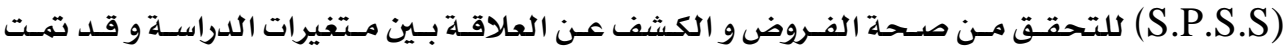

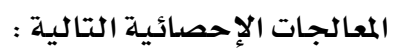

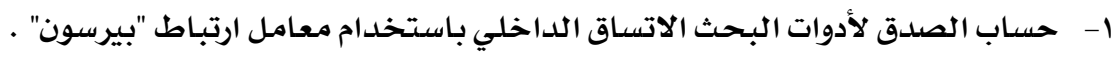

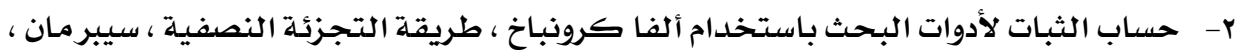
و جيوتمان .

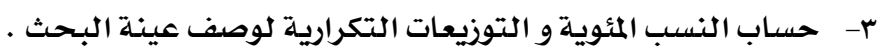
ع- تحليل التباين Analysis Of Variance (ANOVA) الأحسادي لمعرفة دلادلة الفـروق بـين

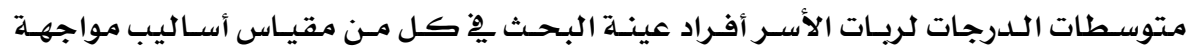

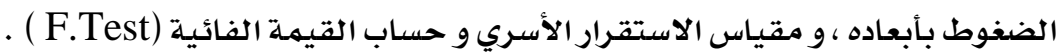

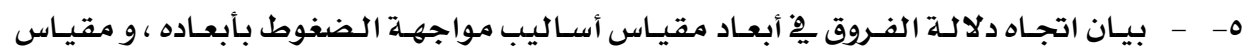

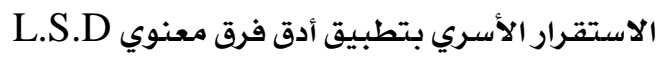

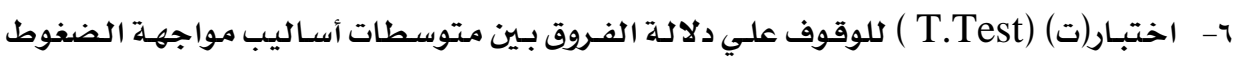

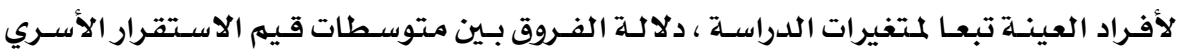

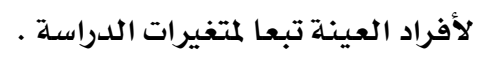

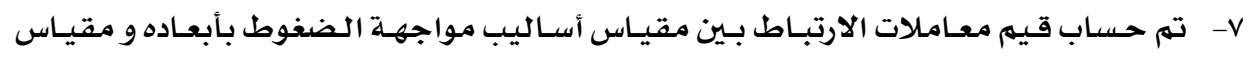

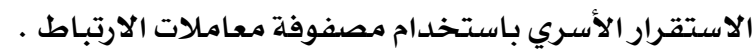

\section{الإفاهيم و المسطحات البحثية :}

Awareness: الوعي

يعرف الوعي من الوجهة اللغوية علي انه الإدراك و الإحاطة ،ووعاه توعية أي اكسب القدرة

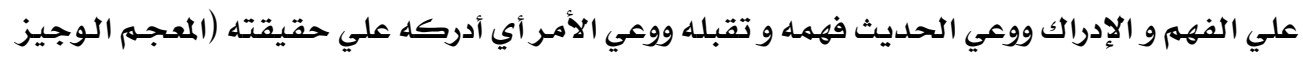
. (1994،

وعرفـه (Victories Websters, 1994) ) بأنسه حالـة يقظــة و انتبـاه للإنسسان و إدراكـا

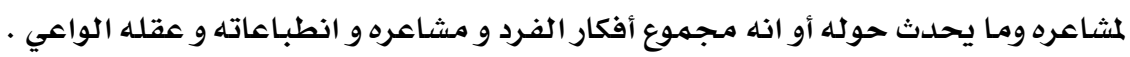

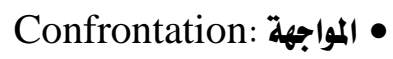

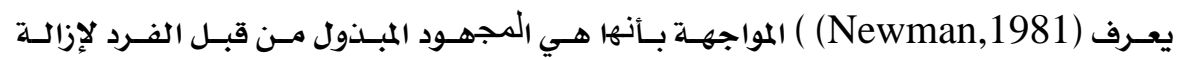

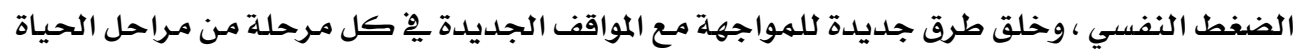

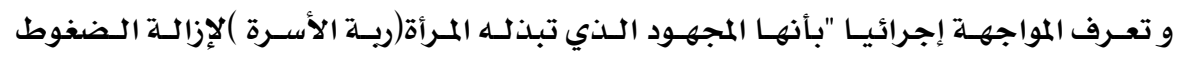

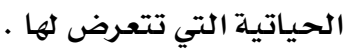




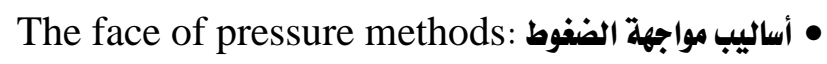
عـرف كـلا مـن (Heaney\&Ryn,1990) أسـاليب مواجهـة الـضغوط "بانها الطـرق الـتي

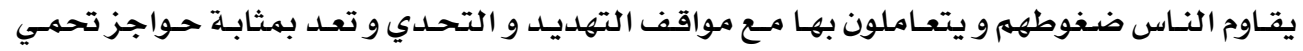

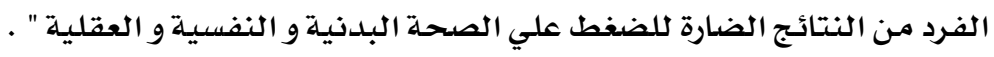

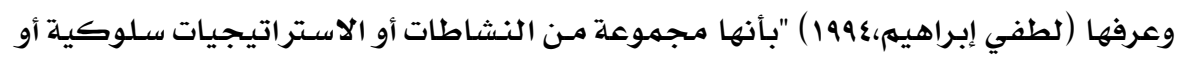

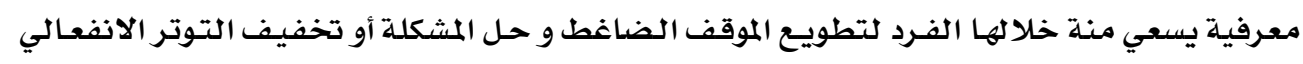

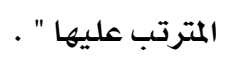

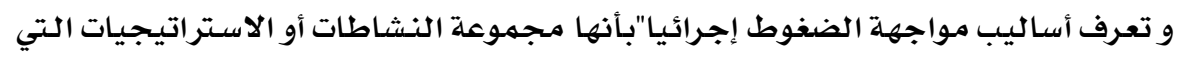

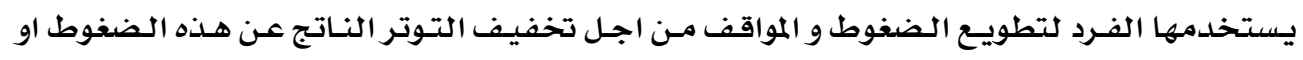

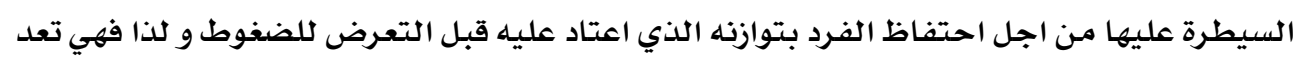

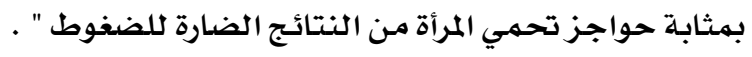
و من أساليب مواجهة الضغوط ما يلي :

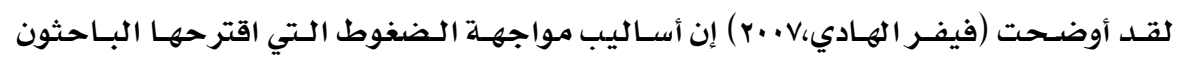

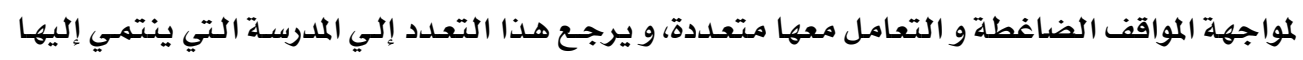

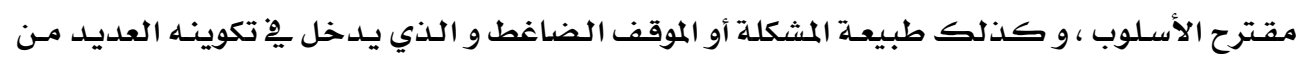

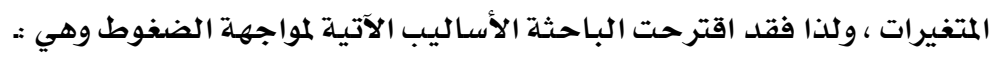

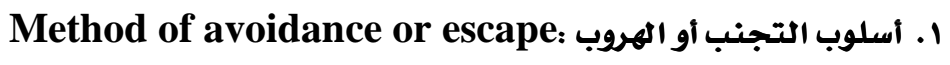

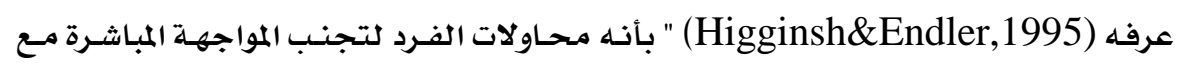
المواقف الضاغطة و ان يكتفي بالانسحاب من هذه المواقف " .

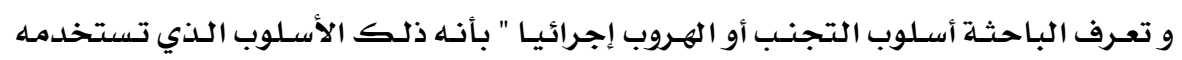

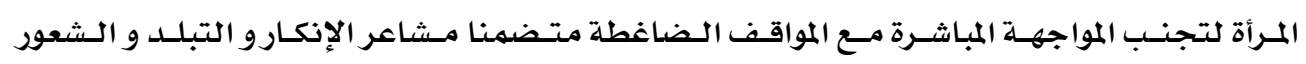

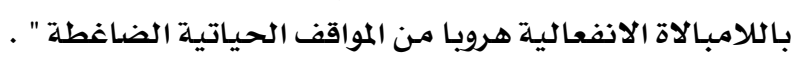

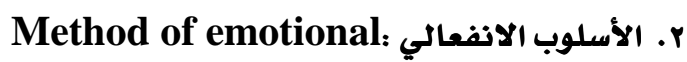

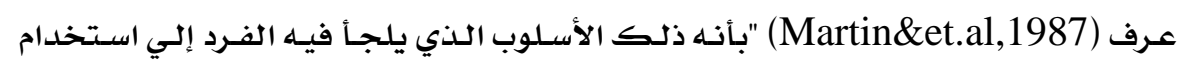

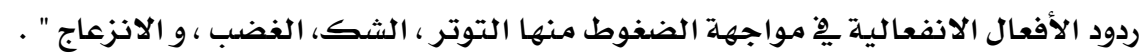

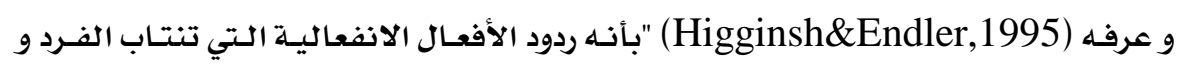

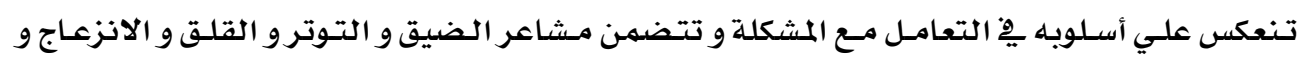

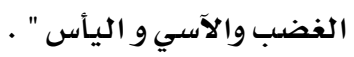

و تعرف الباحثة الأسلوب الانفعالي إجرائيا" بأنه الأسلوب الدني تستخلدمـه المرأة كوسيلة

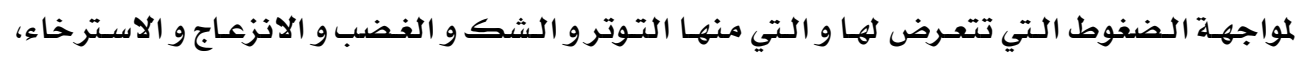

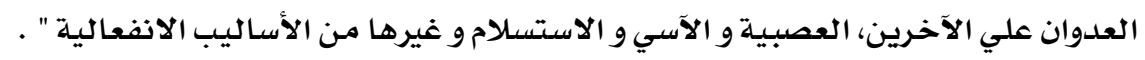


r. Rational method: الأسلوب العقلاني عرفه (Cohen,1994) " بأنه ذلك الإستراتيجية التي يلجـأ إليها الفـرد متضمنـة التفكير المنطقي بحثا عن مصدادر القلق و أسبابه المرتبطة بـالضغوط" .

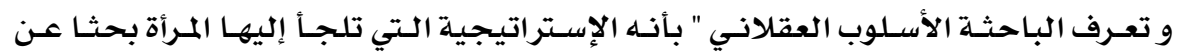
مصادرو أسبـاب الضغوط مستخدمة التفكير المنطقي و الموضوعي يْو وضع هذه الإستراتيجيـة " .

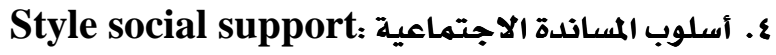

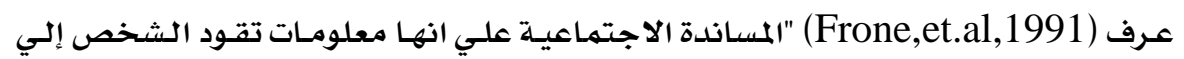

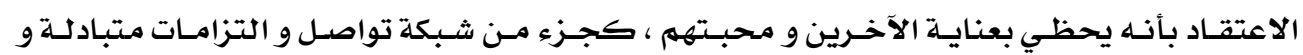

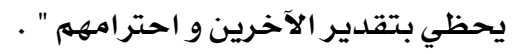

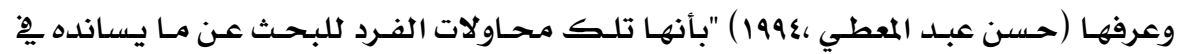

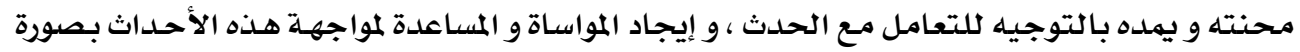

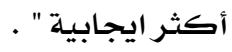

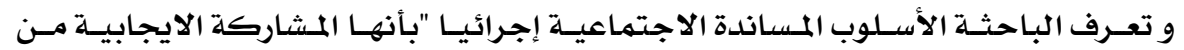

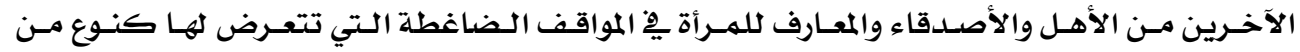

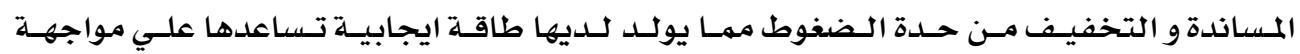
الضغوط" .

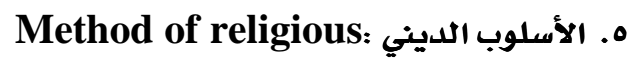

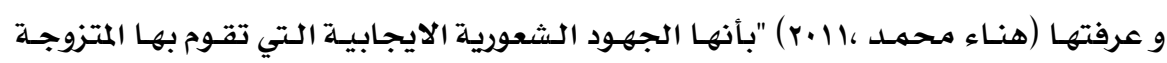

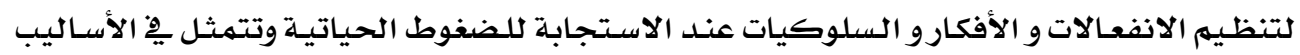

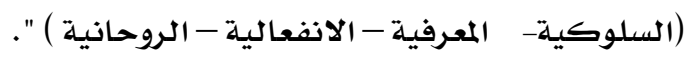

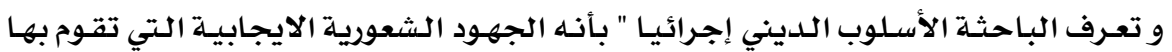

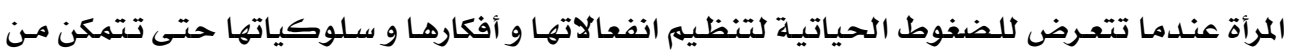

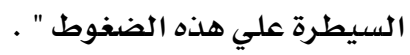

Tertain methods of exercise habits:

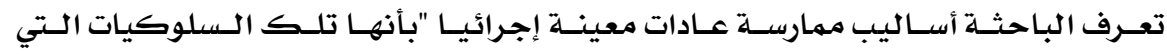

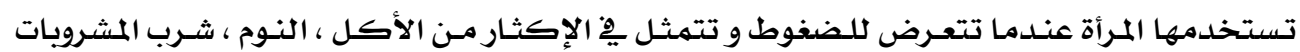

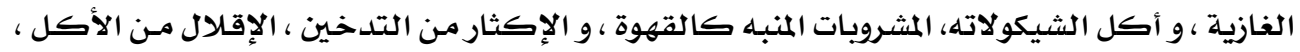

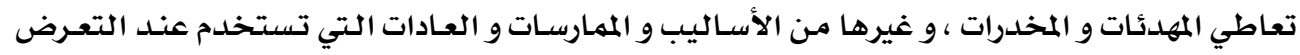
للضغوط " . تصاصي 
Family pressures:

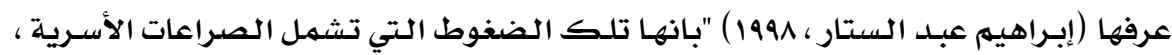

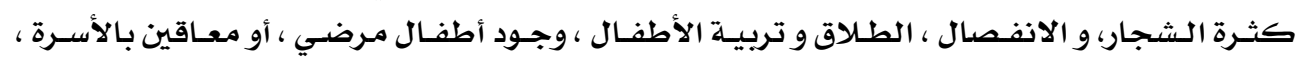

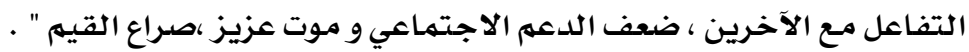

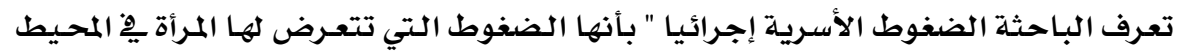

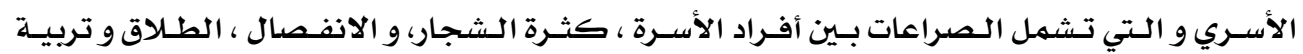

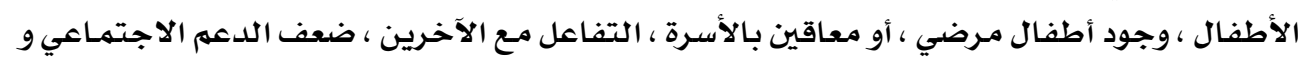

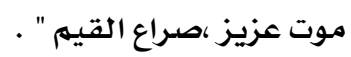

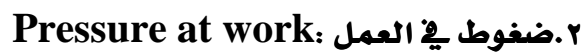

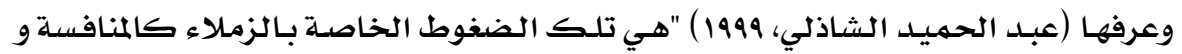

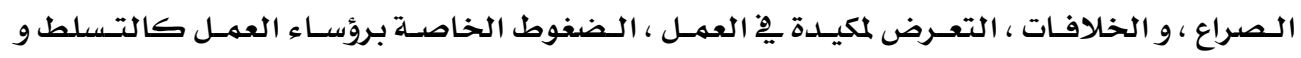

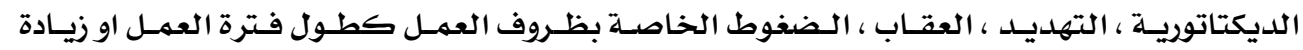

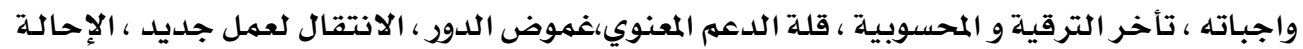

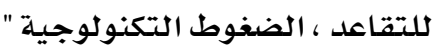

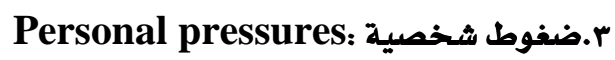

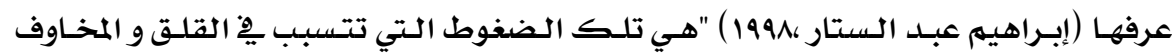

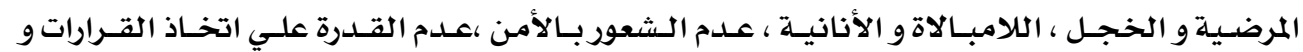
انخفاض مستوي الطموح و الفشل العاطفي و غيرها " . .

Social pressures: ضغوط اجتماعية

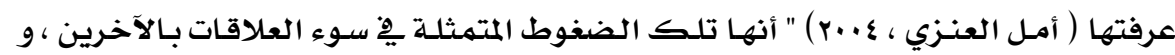

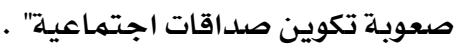

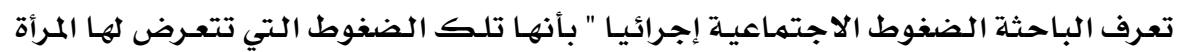

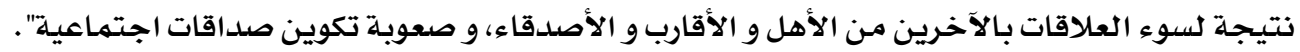
الاستقرار: Stability

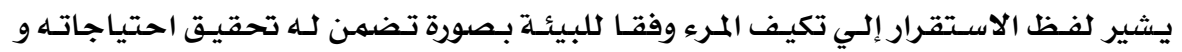

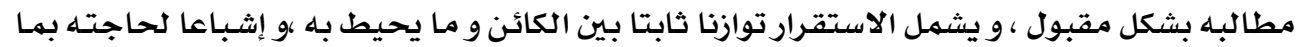

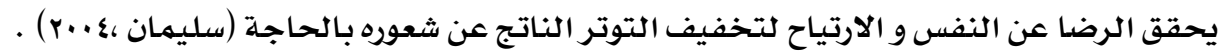

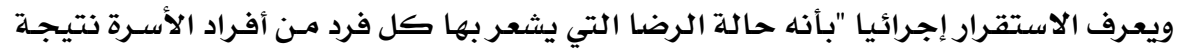

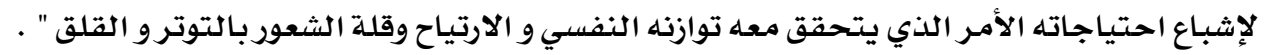


Family stability: الاستقرار الأسري

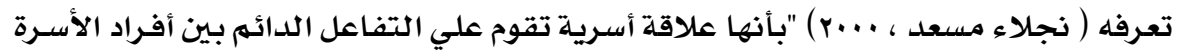

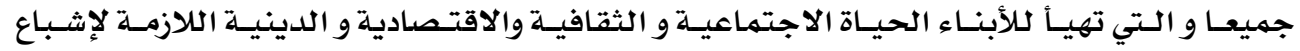

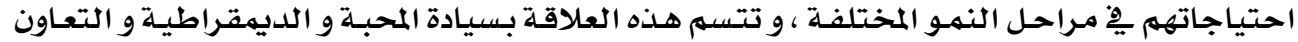

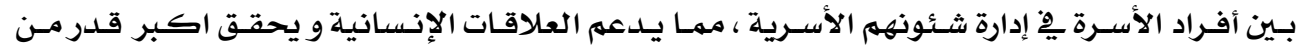
التماسك و التقارب داخل الأسرة " .

تعـرف الباحثـة الاسـتقرار الأسـري إجـرائيـا" بأنها العلاقـة الأسـريـة التي تقوم علـي التفاعل

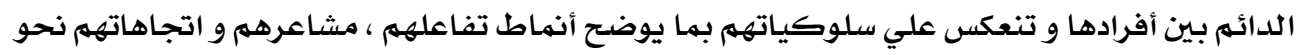

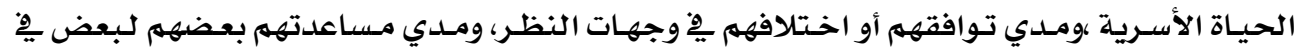

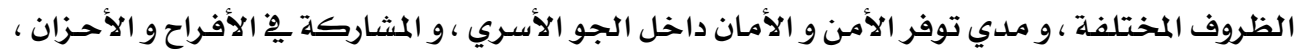

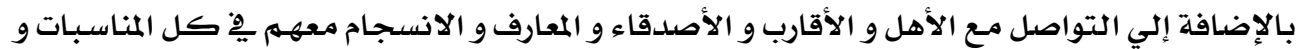

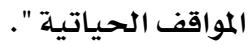

\section{نتائج الدراسة الميدانية :}

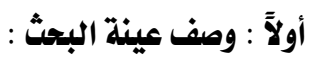

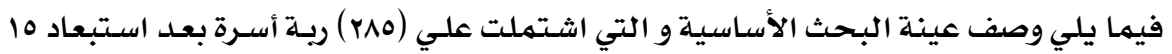

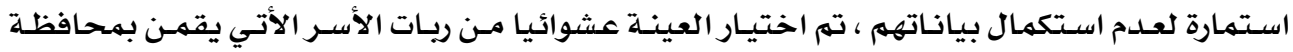

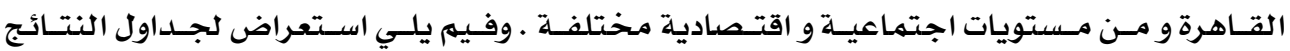
الوصفية لعينة البحث : 


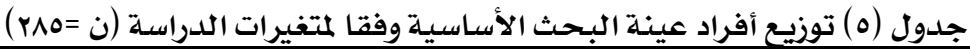

\begin{tabular}{|c|c|c|}
\hline النسبة. & 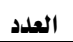 & عمر الزوجة \\
\hline$\%$ rq, & $\wedge \varepsilon$ & أقل من •r سنة \\
\hline$\%$ \%l, & q. & من ·r سنة إلي أقل من •؛ سنة \\
\hline$\%$ \% & 111 & من •ـ سنة فأكثر \\
\hline$\%$ & rao & المجموع \\
\hline النسبة. & العدد & تعليم الزوج \\
\hline$\% r \vee, \xi$ & vi & الثانوية العامة أو ما يعادلها \\
\hline$\%$ rr, r & 94 & 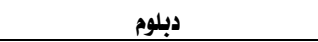 \\
\hline$\%\{\bullet, \varepsilon$ & 110 & بكالوريوس أو ليسانس / دراسات عليا \\
\hline$\%$ & rao & المجموع \\
\hline النسبة. & العدد & تعليم الزوجة \\
\hline$\%$ \%,$\wedge$ & 10 & الثانوية العامة أو ما يعادلها \\
\hline$\%$ rI, 7 & q. & 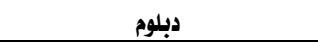 \\
\hline$\%$ \%А, 7 & $11 \cdot$ & بكالوريوس أو ليسانس / دراسات عليا \\
\hline$\% 1 \cdots$ & rao & المجموع \\
\hline النسبة. & العدد & عمل الأم \\
\hline$\% 09,7$ & iv. & تعمل \\
\hline$\%\{\bullet, \varepsilon$ & 110 & لا تعمل \\
\hline$\% 1 \cdots$ & rao & المجموع \\
\hline النسبة. & العدد العد & عدد سنوات الزواج \\
\hline$\%$ & Av & أقل من •ا سنوات \\
\hline$\%$ \&r, r & Irr & من •ا سنوات الي أقل من 10 سنة \\
\hline$\%$ \% & vo & من 10 سنة فأكثر \\
\hline$\% 1 \cdot$ & rao & المجموع \\
\hline النسبة. & العدد & عدد أفراد الأسرة \\
\hline$\%$ r^,1 & A. & أقل من § أفراد \\
\hline$\% r q, r$ & lir & من ₹ أفراد الي 7 أفراد \\
\hline$\%$ \%r, & 94 & v أفراد فأكثر \\
\hline$\% 1 \cdots$ & rao & المجموع \\
\hline النسبة/ & العدد & الدخل الشهري \\
\hline$\%$ IA,r & or & اقل من .... جنيه \\
\hline$\% 1,9$ & rI & 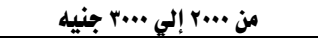 \\
\hline$\% 9,0$ & rv & 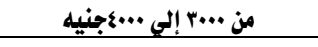 \\
\hline$\% \Gamma 1, \Lambda$ & 7r & من •..؛ إلي •..0 جنيه \\
\hline$\% 10,1$ & $\xi r$ & من •."0 إلي •..7 جنيه \\
\hline$\% \mathbb{Y}\rceil$, & v. & ..... جنيه فأكثر \\
\hline$\% \cdots$ & ras & المجموع \\
\hline
\end{tabular}


ثانيا : النتائج في ضوء الفروض : الفرض الأول :

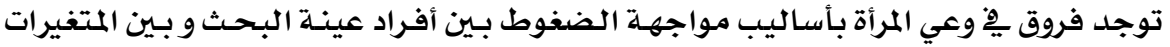

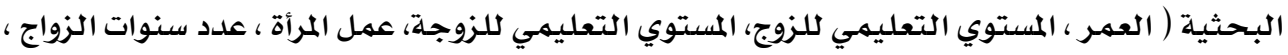

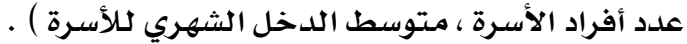
وللتحقق من صحة الفرض تم حسـاب دلالـة الفـروق باستخدام اختبـار T. Test للمستغيرات ثنائية الأبعاد ، اختبار F. test لتحليل التباين للمتغيرات ثلاثية الأبعاد . جدول (7) الفروق بين المتوسطات الحسابية يِّوعي المرأة بأساليب مواجهة الضغوط لأفراد عينة

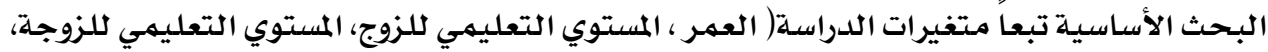

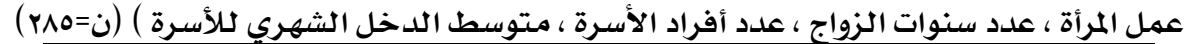

\begin{tabular}{|c|c|c|c|c|c|}
\hline الدلالة & قيمة (ف) & درجات الحرية & متوسط المربعات & مجموع المربعات & العمر \\
\hline \multirow{2}{*}{ ل } & \multirow{2}{*}{61.192} & 2 & 320861.081 & 641722.163 & بين المجموعات \\
\hline & & 282 & 5243.511 & 1478670.013 & داخل المجموعات \\
\hline & & 284 & & 2120392.176 & المجموع \\
\hline الدلالة & قيمة ( ف) & درجات الحرية & متوسط المربعات & مجموع المربعات & تعليم الزوج \\
\hline \multirow{3}{*}{ | } & \multirow{2}{*}{43.341} & 2 & 275540.931 & 551081.863 & بين المجموعات \\
\hline & & 282 & 6357.513 & 1792818.579 & داخل المجموعات \\
\hline & & 284 & & 2343900.442 & المجموع \\
\hline الدلالة & قيمة ( ف) & |درجات الحرية & متوسط المربعات & مجموع المربعات & تعليم الزوجة \\
\hline \multirow{3}{*}{ - 0.01 دال } & \multirow{2}{*}{61.345} & 2 & 314789.414 & 629578.828 & بين المجموعات \\
\hline & & 282 & 5131.495 & 1447081.500 & داخل المجموعات \\
\hline & & 284 & & 2076660.328 & المجموع \\
\hline الدلالة & قيمة (ف) & |درجات الحرية & متوسط المربعات & مجموع المربعات & عدد سنوات الزواج \\
\hline \multirow{3}{*}{ ل 0.01 دال } & \multirow{3}{*}{59.729} & 2 & 304974.870 & 609949.741 & بين المجموعات \\
\hline & & 282 & 5105.963 & 1439881.487 & داخل المجموعات \\
\hline & & 284 & & 2049831.228 & المجموع \\
\hline الدلالة & قيمة ( ف) & درجات الحرية & متوسط المربعات & مجموع المربعات & عدد أفراد الأسرة \\
\hline \multirow{3}{*}{ ل 0.01 دال } & \multirow{3}{*}{36.505} & 2 & 214797.320 & 429594.641 & بين المجموعات \\
\hline & & 282 & 5884.094 & 1659314.559 & داخل المجموعات \\
\hline & & 284 & & 2088909.200 & المجموع \\
\hline الدلالة & قيمة ( ف) & |درجات الحرية & متوسط المربعات & مجموع المربعات & الدخل الشهري للأسرة \\
\hline ( 0.01 دال & 37.442 & 2 & 270310.001 & 540620.003 & بين المجموعات \\
\hline
\end{tabular}


وعي المرأة بأساليب مواجهة الضغوط و علاقته بالاستقرار الأسري

\begin{tabular}{||l|l|l|l|l||c||}
\hline & & 282 & 7219.524 & 2035905.727 & داخل المجيموع|| \\
\hline & & 284 & & 2576525.730 & \\
\hline
\end{tabular}

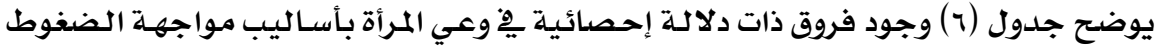

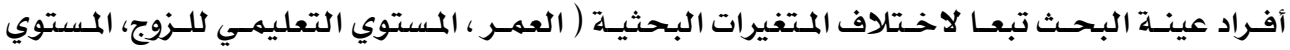

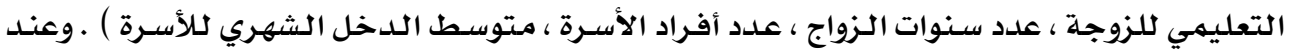

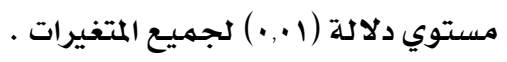

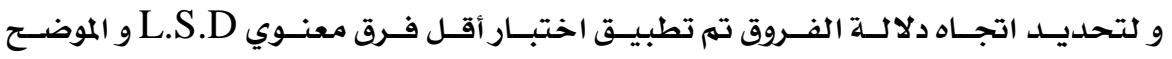

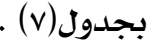

جدول (v) دلالة الفروق بين ريات الأسر أفراد عينة البحث الأساسية يِّ الوعي بأساليب مواجهة

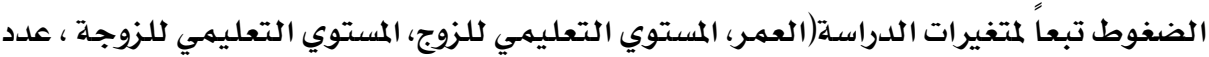

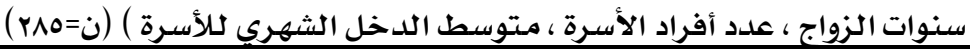

\begin{tabular}{|c|c|c|c|}
\hline من •؛ سنة فأكثر م= 250.828 & من •r سنة الي أقل من •؛ سنة & أقل من •r سنة & العمر \\
\hline & & - & أقل من •r سنة \\
\hline & - & $* * 71.557$ & من •r سنة الي أقل من •ع سنة \\
\hline- & $* * 66.306$ & $* * 137.864$ & من •ع سنة فأكثر \\
\hline \multirow[t]{3}{*}{ بكالوريوس أو ليسانس / دراسات عليا } & مبلو = & $\begin{array}{c}\text { الثانوية العامة أو ما يعادلها } \\
111.076=\end{array}$ & 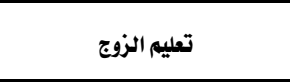 \\
\hline & & - & الثانوية العامة أو ما يعادلها \\
\hline & - & $* * 68.944$ & دبلوم \\
\hline- & $* * 69.647$ & $* * 138.592$ & بكالوريوس أو ليسانس / دراسات عليا \\
\hline \multirow[t]{3}{*}{ بكالوريوس أو ليسانس / دراسات عليا } & 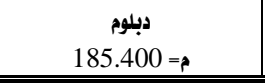 & $\begin{array}{c}\text { الثانوية العامة أو ما يعادلها } \\
113.294= \\
\end{array}$ & 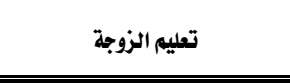 \\
\hline & & - & الثانوية العامة أو ما يعادلها \\
\hline & - & $* * 72.105$ & 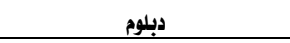 \\
\hline- & $* * 65.709$ & $* * 137.814$ & بكالوريوس أو ليسانس / دراسات عليا \\
\hline \multirow[t]{3}{*}{ من 10 سنة فأكثر م= 260.586} & $\begin{array}{c}\text { من •ا سنوات الي أقل من } 10 \text { سنة } 199.016= \\
\end{array}$ & أقل من •ا سنوات م= 113.965 & عدد سنوات الزواج \\
\hline & & - & أقل من •ا سنوات \\
\hline & - & $* * 85.050$ & من · سنوات الي أقل من 10 سنة \\
\hline- & $* * 61.570$ & $* * 146.621$ & من 10 سنة فأكثر \\
\hline \multirow[t]{3}{*}{$\begin{array}{l}\text { r أفراد فأكثر r } \\
116.064\end{array}$} & $\begin{array}{c}\text { من ₹ أفراد الي } 7 \text { أفراد } 223.428=0 \\
\end{array}$ & أقل من ع أفراد & عدد أفراد الأسرة \\
\hline & & - & أقل من ع أفراد \\
\hline & - & *3.071 & من ع أفراد الي ح أفراد \\
\hline - & $* * \mathbf{1 0 7 . 3 6 4}$ & $* * 110.435$ & v أفراد فأكثر \\
\hline \multirow[t]{2}{*}{$\begin{array}{c}\text { مرتفع = } 250.256 \\
250.20\end{array}$} & $\begin{array}{c}\text { متوسط = } 151.056 \\
15\end{array}$ & منغفض = & اللدخل الشهري للأسرة \\
\hline & & - & منخفض \\
\hline
\end{tabular}




\begin{tabular}{|c|c|c|c|}
\hline & - & $* 3.887$ & متوسط \\
\hline- & $* * 99.200$ & $* * 103.087$ & مرتفع \\
\hline
\end{tabular}

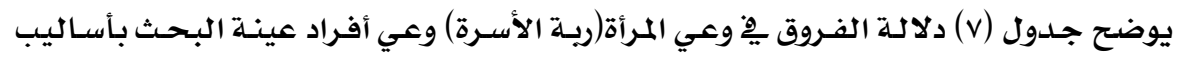

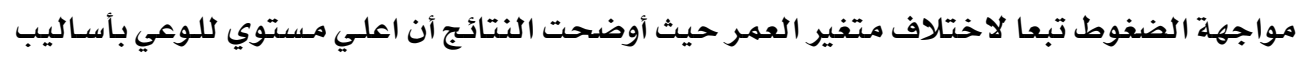

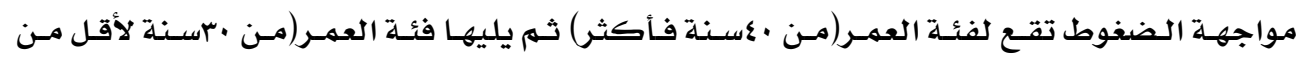

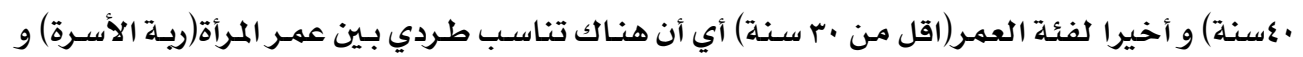

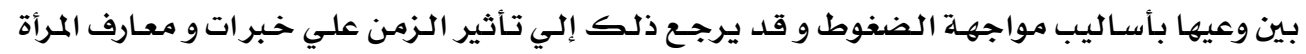

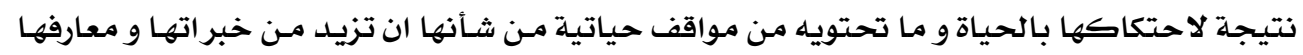

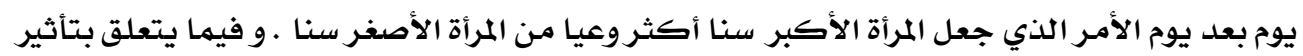

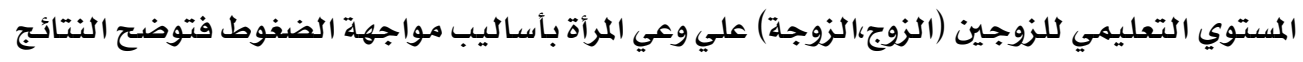

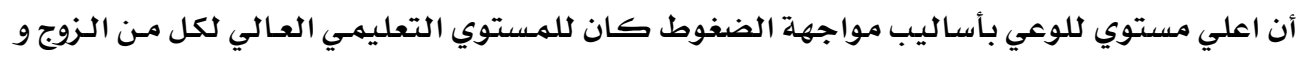

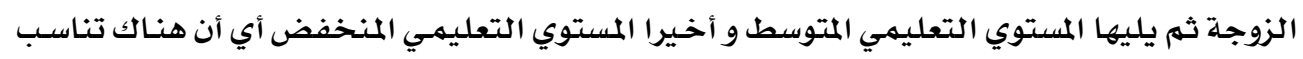

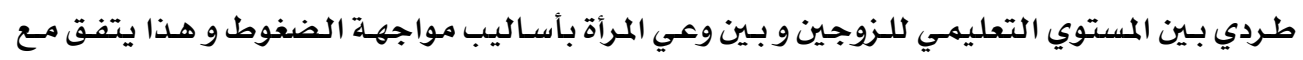

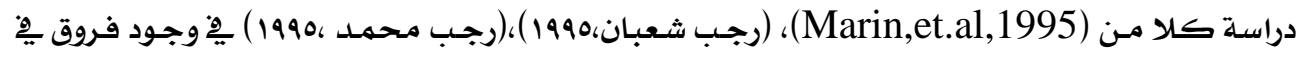

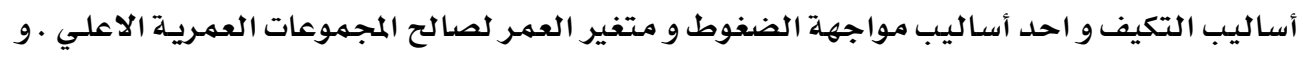

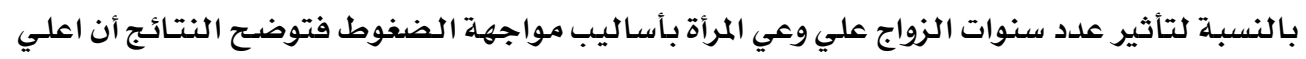

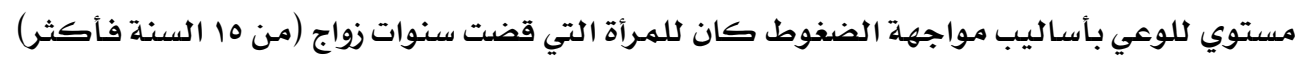

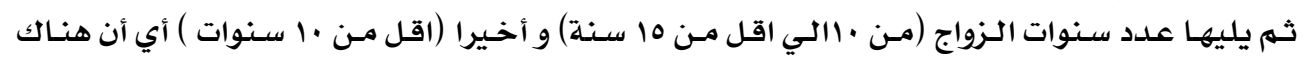

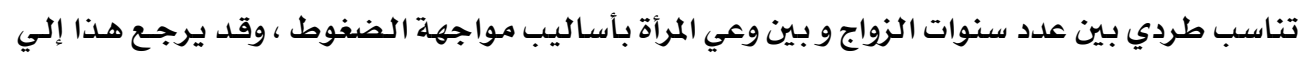

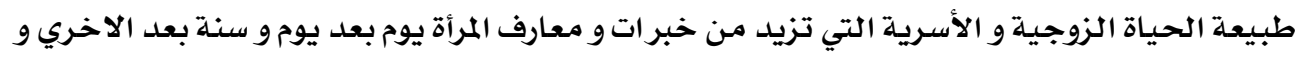

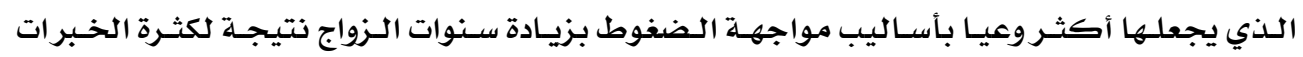

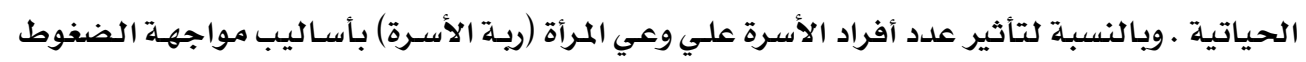

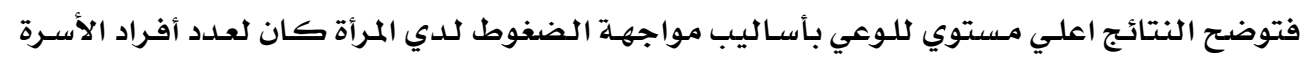
(اقل من ع أفراد )

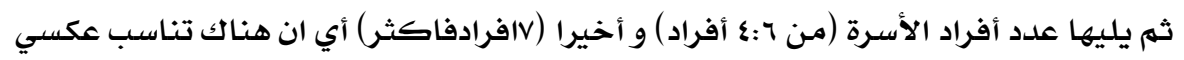

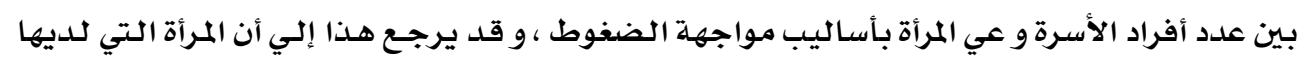

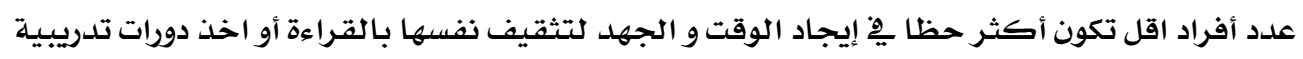

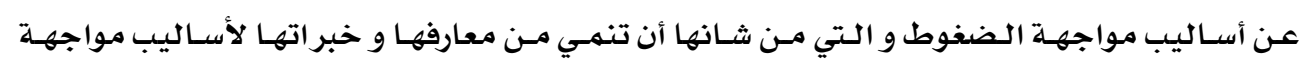

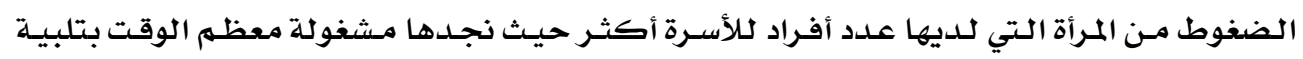

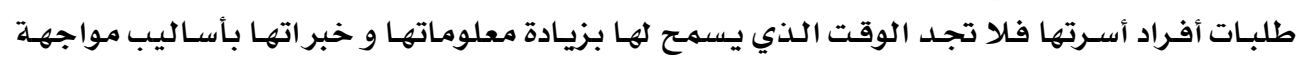

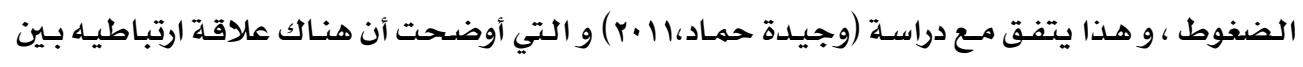

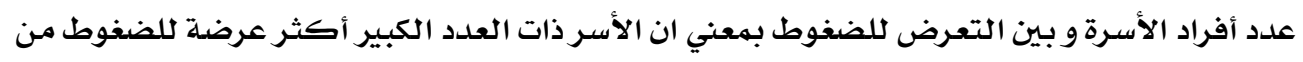

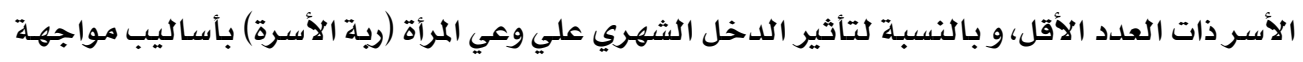




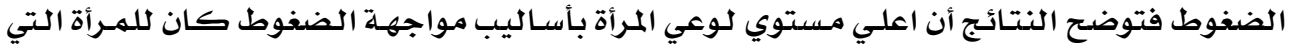

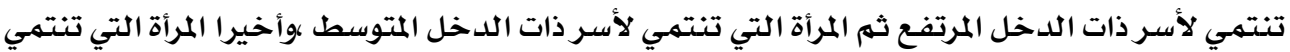

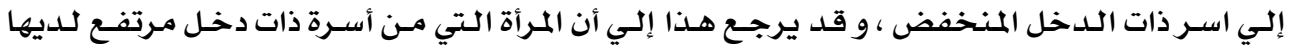

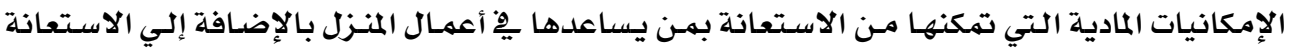

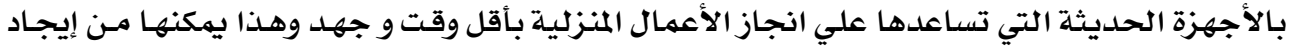

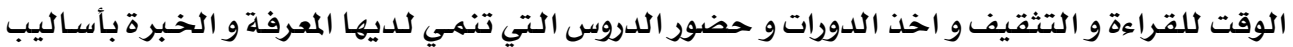

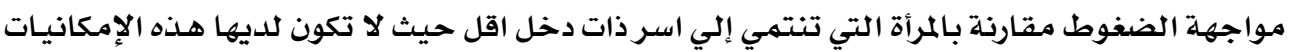

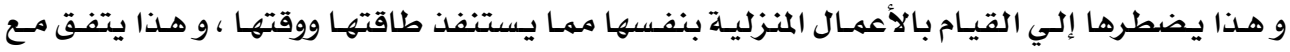

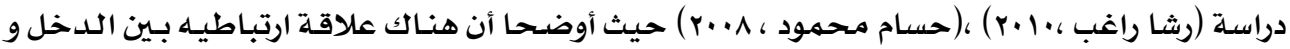

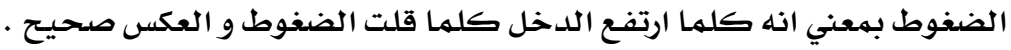

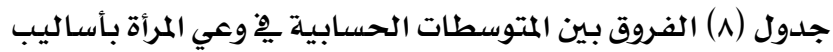

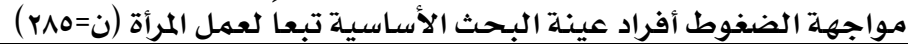

\begin{tabular}{|c|c|c|c|c|c|c|}
\hline الدلالة & قيمة (ت) & درجات الحرية & العينة & الانحراف المعياري & المتوسط الحسابي & عمل المرأة \\
\hline \multirow{2}{*}{ دال عند 0.01 لصالح } & \multirow{2}{*}{33.049} & \multirow{2}{*}{283} & 170 & 29.179 & 233.017 & تعمل \\
\hline & & & 115 & 23.906 & 124.565 & لا تعطل \\
\hline
\end{tabular}

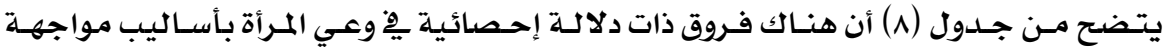

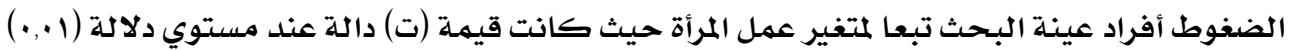

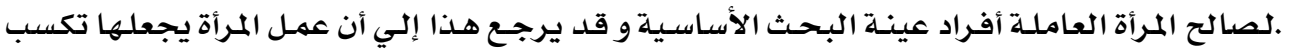

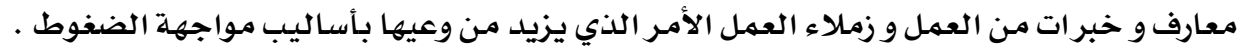

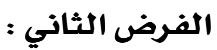

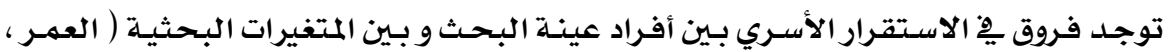

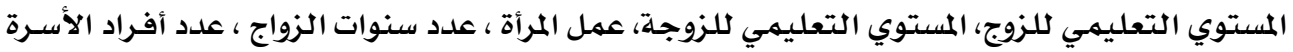
، متوسط الدخل الشهري للأسرة ) . وللتحقق من صحة الفرض تم حسـاب دلالـة الفـروق باستخدام اختبـار T. Test للمستغيرات ثنائية الأبعاد ، اختبار F. test لتحليل التباين للهتغيرات ثلاثية الأبعاد . 


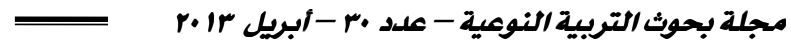

جدول (ه) الفروق بين المتوسطات الحسابية يِ الاستقرار الأسري لأفراد عينة البحث الأساسية تبعاً

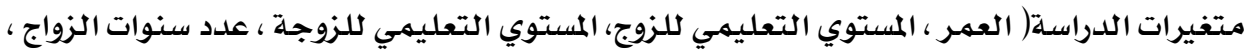

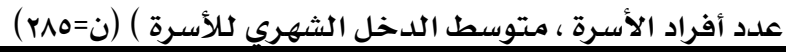

\begin{tabular}{|c|c|c|c|c|c|}
\hline الدلالة & قيمة (ف) & درجات الحرية & متوسط المربعات & مجموع المربعات & العمر \\
\hline \multirow{3}{*}{0.01 دال } & \multirow{2}{*}{47.722} & 2 & 86680.069 & 173360.139 & بين المجموعات \\
\hline & & 282 & 1816.371 & 512216.511 & داخل المجموعات \\
\hline & & 284 & & 685576.650 & المجموع \\
\hline الدلالة & قيمة (ف) & درجات الحرية & متوسط المربعات & مجموع المربعات & تعليم الزوج \\
\hline \multirow{3}{*}{0.01 دال } & \multirow{2}{*}{41.470} & 2 & 83770.850 & 167541.699 & بين المجموعات \\
\hline & & 282 & 2020.034 & 569649.537 & داخل المجموعات \\
\hline & & 284 & & 737191.236 & المجموع \\
\hline الدلالة & قيمة (ف) & درجات العرية & متوسط المربعات & مجموع المربعات & تعليم الزوجة \\
\hline \multirow{3}{*}{0.01 داJ } & \multirow{2}{*}{43.296} & 2 & 85804.963 & 171609.926 & بين المجموعات \\
\hline & & 282 & 1981.806 & 558869.234 & داخل المجموعات \\
\hline & & 284 & & 730479.160 & المجموع \\
\hline الدلالة & قيمة (ف) & درجات الحرية & متوسط المربعات & مجموع المربعات & عدد سنوات الزواج \\
\hline \multirow{3}{*}{0.01 داJ } & \multirow{2}{*}{37.349} & 2 & 62035.489 & 124070.978 & بين المجموعات \\
\hline & & 282 & 1660.989 & 468398.780 & داخل المجموعات \\
\hline & & 284 & & 592469.758 & المجموع \\
\hline الدلالة & قيمة (ف) & درجات الحرية & متوسط المربعات & مجموع المربعات & عدد أفراد الأسرة \\
\hline \multirow{3}{*}{0.01 دار } & \multirow{2}{*}{29.568} & 2 & 50971.542 & 101943.084 & بين المجموعات \\
\hline & & 282 & 1723.846 & 486124.705 & داخل المجموعات \\
\hline & & 284 & & 588067.789 & المجموع \\
\hline الدلالة & قيمة (ف) & درجات الحرية & متوسط المربعات & مجموع المربعات & الدخل الشهري للأسرة \\
\hline \multirow{3}{*}{0.01 دال } & \multirow{2}{*}{44.800} & 2 & 85730.098 & 171460.195 & بين المجموعات \\
\hline & & 282 & 1913.603 & 539636.067 & داخل المجموعات \\
\hline & & 284 & & 711096.262 & المجموع \\
\hline
\end{tabular}

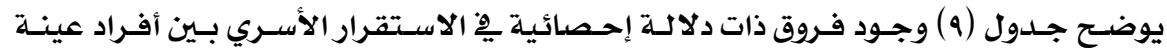

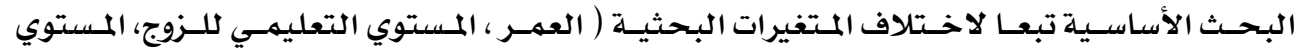




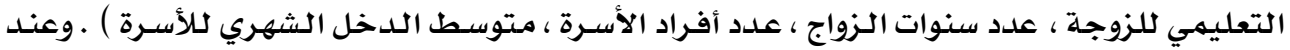

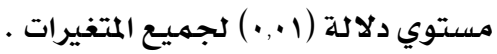

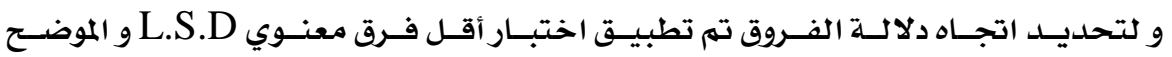

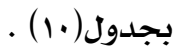

جدول ( • ) دلالة الفروق بين ربات الأسر أفراد عينة البحث الأساسية يِّ الاستقرار الأسري لأفراد عينة

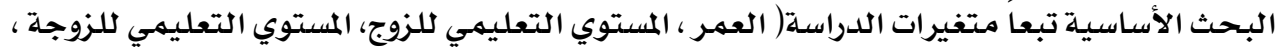

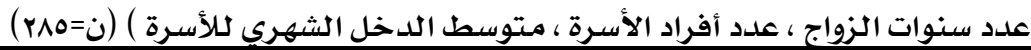

\begin{tabular}{|c|c|c|c|}
\hline من •؛ سنة فأكثر م= 125.000 & من •r سنة الي أقل من •ع سنة & أقل من •r سنة & 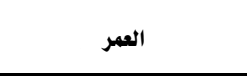 \\
\hline & & - & أقل من •r سنة \\
\hline & - & $\pm \times 40.636$ & من ·r سنة الي أقل من •ـ سنة \\
\hline- & $* * 28.077$ & $\pm * 68.714$ & من •ـ سنة فأكثر \\
\hline \multirow[t]{3}{*}{$\begin{array}{c}\text { بكالوريوس أو ليسانس / دراسات عليا } \\
\text { ب = } 124.426 \\
\end{array}$} & 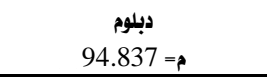 & الثانوية العامة أو ما يعادلها & تعليم الزوج \\
\hline & & - & الثانوية العامة أو ما يعادلها \\
\hline & - & $* * 39.811$ & 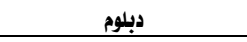 \\
\hline- & $* 2 \times 29.589$ & $* * 69.400$ & بكالوريوس أو ليسانس / دراسات عليا \\
\hline \multirow[t]{3}{*}{$\begin{array}{c}\text { بكالوريوس أو ليسانس / دراسات عليا } \\
\text { م= } 125.136\end{array}$} & مبلم= دبلوم 97.311 & 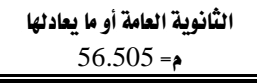 & ت تعليم الزوجة \\
\hline & & - & الثانوية العاهة أو ما يعادلها \\
\hline & - & $\pm * 40.805$ & 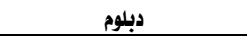 \\
\hline- & $* * 27.825$ & $\pm * 68.630$ & بكالوريوس أو ليسانس / دراسات عليا \\
\hline \multirow[t]{3}{*}{ من 10 سنة فأكثر م= 115.360} & من • م سنوات الي أقل من 10 سنة & أقل من • اننوات م= 56.942 & علد سنوات الزواج \\
\hline & & - & أقل من •ا سنوات \\
\hline & - & $\pm * 54.602$ & من • اسنوات الي أقل من 10 سنة \\
\hline- & $* 3.815$ & $\pm * 58.417$ & من 10 سنة فأكثر \\
\hline \multirow[t]{3}{*}{$82.871=$} & 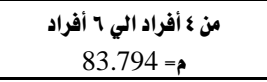 & أقل من § أفراد 127.925 أ 127. & عدد أفراد الأسرة \\
\hline & & - & أقل من ؟ أفراد \\
\hline & - & $\pm * 44.130$ & من ع أفراد الي 7 أفراد \\
\hline- & 0.923 & $\pm * 45.054$ & V ا أفراد فأكثر \\
\hline \multirow[t]{4}{*}{$\begin{array}{c}\text { مرتفع } 124.716 \\
\end{array}$} & متوسط = مت & 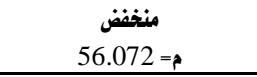 & الدخل الشهري للأسرة \\
\hline & & - & 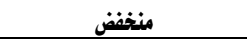 \\
\hline & - & $* * 40.320$ & متوسط \\
\hline & $* 28.323$ & $* * 68.644$ & مرتفع \\
\hline
\end{tabular}




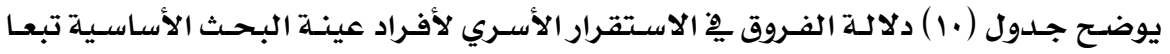

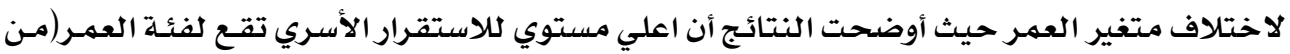

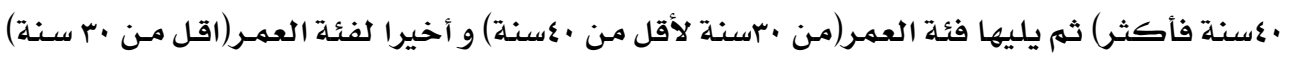

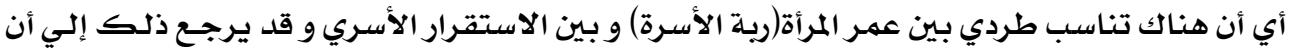

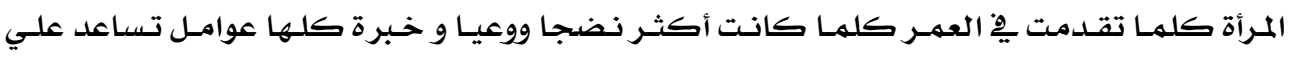

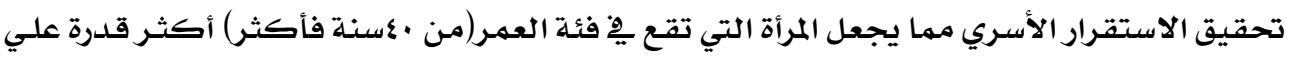

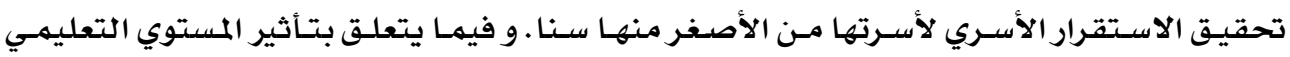

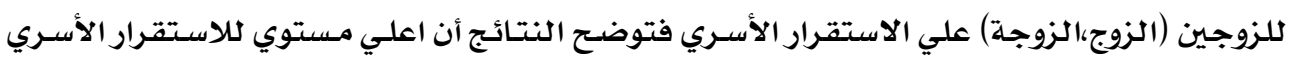

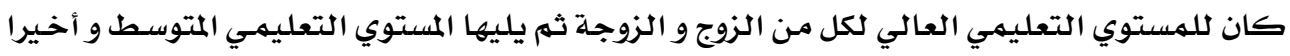

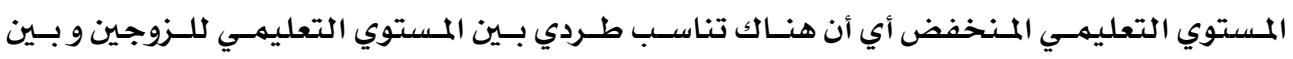

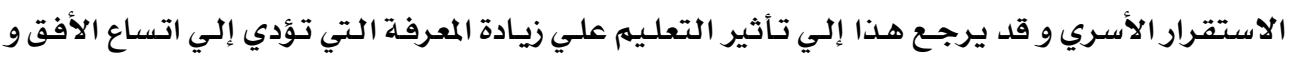

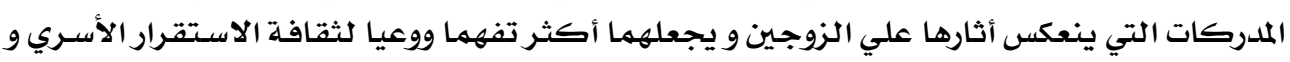

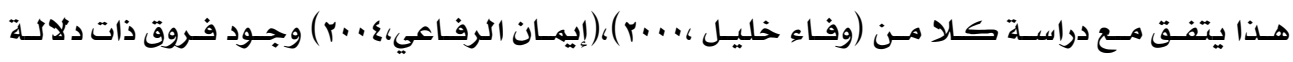

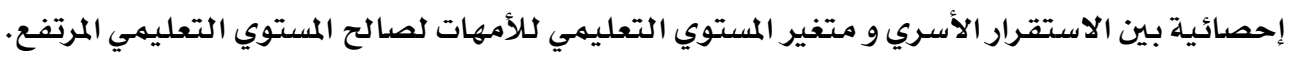

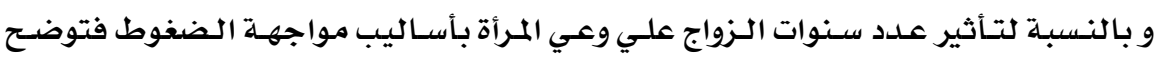

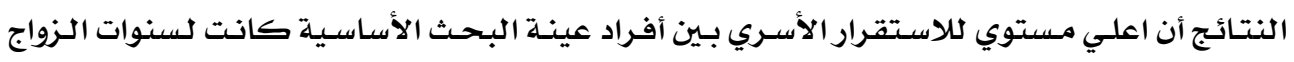

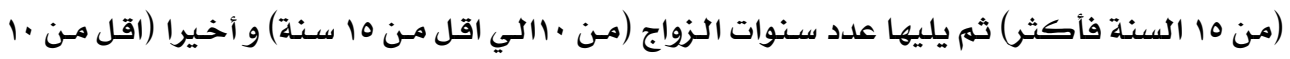

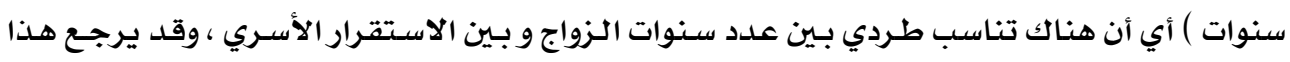

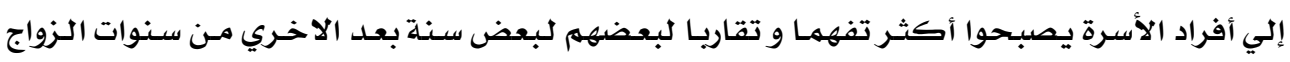

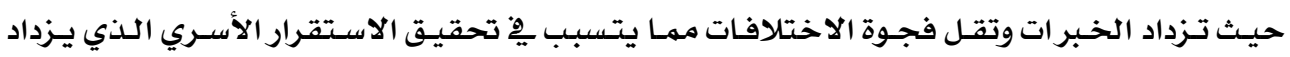

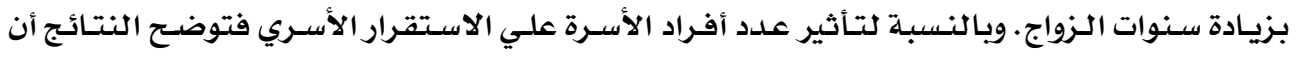

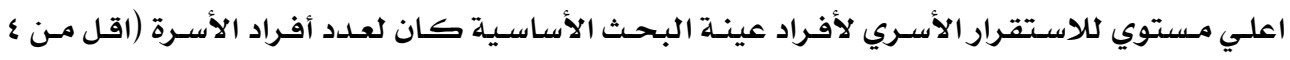

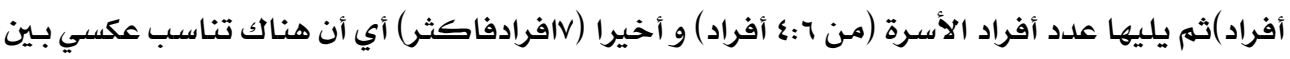

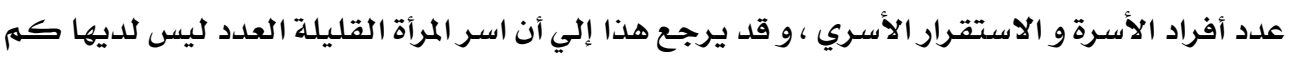

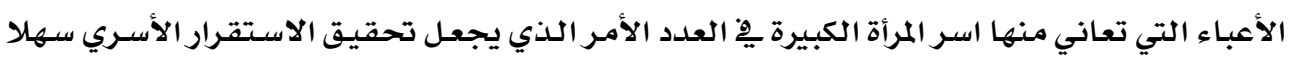

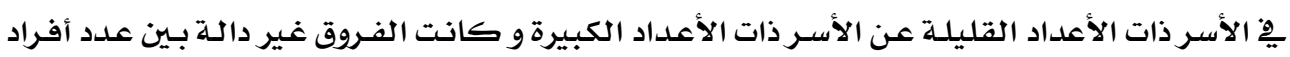

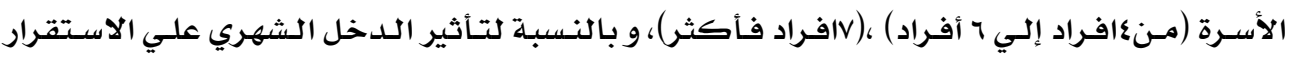

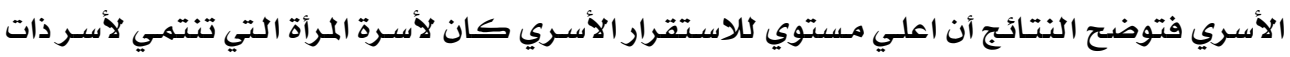

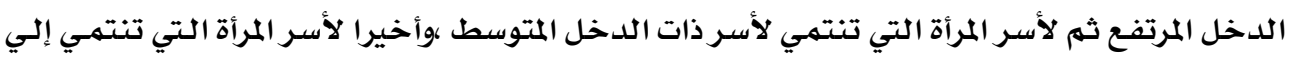

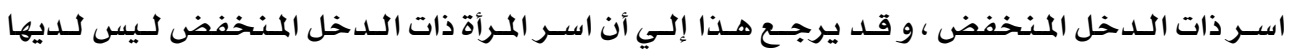

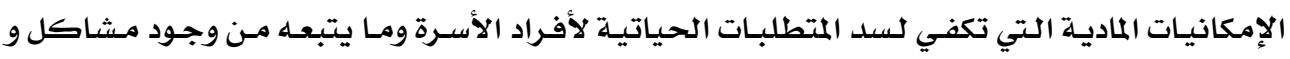

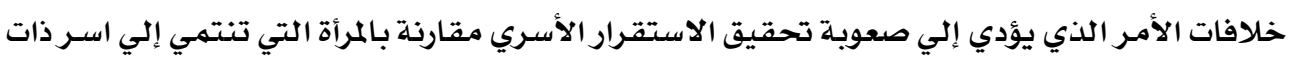

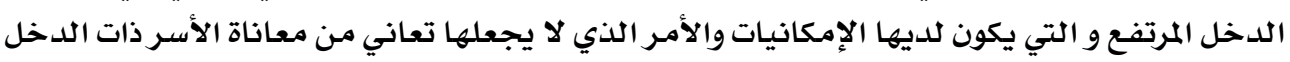


الأقل وبالتـالي فهي أكثر حظا لتحقيق الاستقرار الأسـري ، و هـذا يتفق مـع دراسـة كـلا مـن (وفـاء

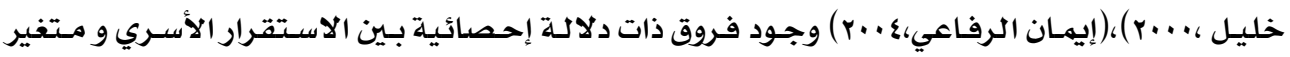

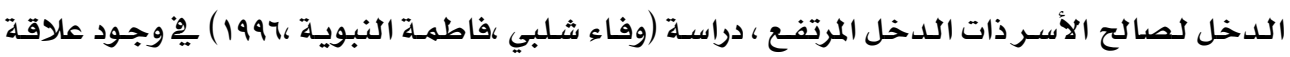

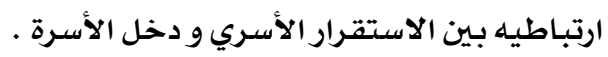

جدول (11) الفروق بين المتوسطات الحسابية يِّ الاستقرار الأسري

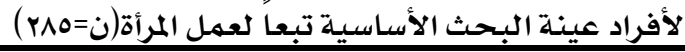

\begin{tabular}{|c|c|c|c|c|c|c|}
\hline الدلالة & قيمة (ت) & درجات الحرية & العينة & الانحراف الميياري & المتوسط الحسابي & عمل المرأة \\
\hline \multirow{2}{*}{0.713 غير دال } & \multirow{2}{*}{0.368} & \multirow{2}{*}{283} & 170 & 22.604 & 95.352 & تعمل \\
\hline & & & 115 & 37.404 & 96.660 & لا تعمل \\
\hline
\end{tabular}

يتضـح مـن جـدول (1) أنـه لا توجـد فروق ذات دلالـة إحصائية يِ الاسـتقرار الأسـري لأفراد

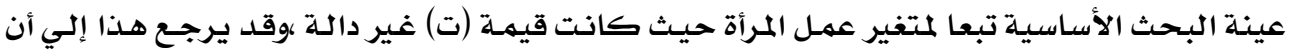

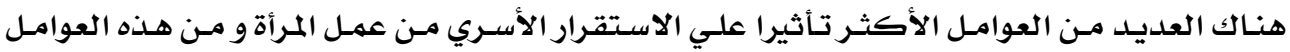

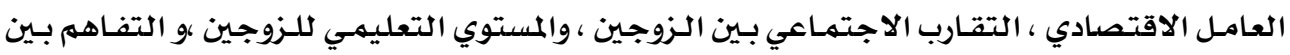

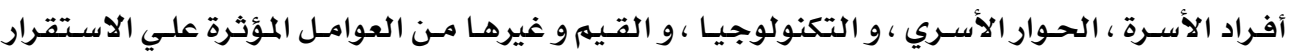

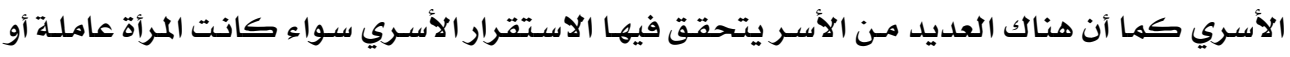

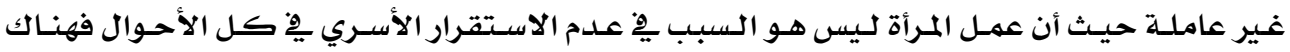

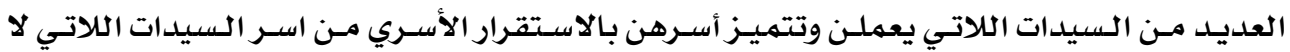

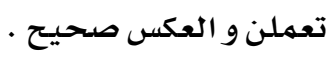

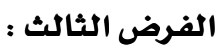

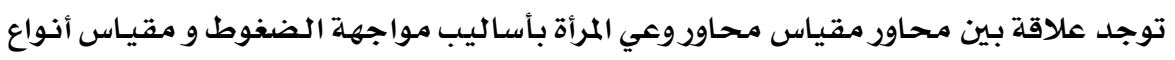

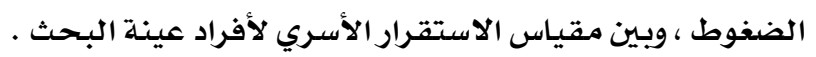

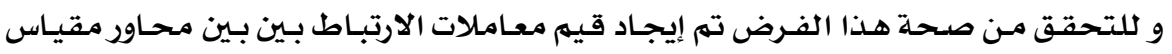

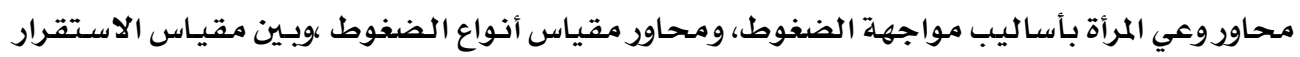
الأسري و جدول (rا ) يوضح ذلك. 


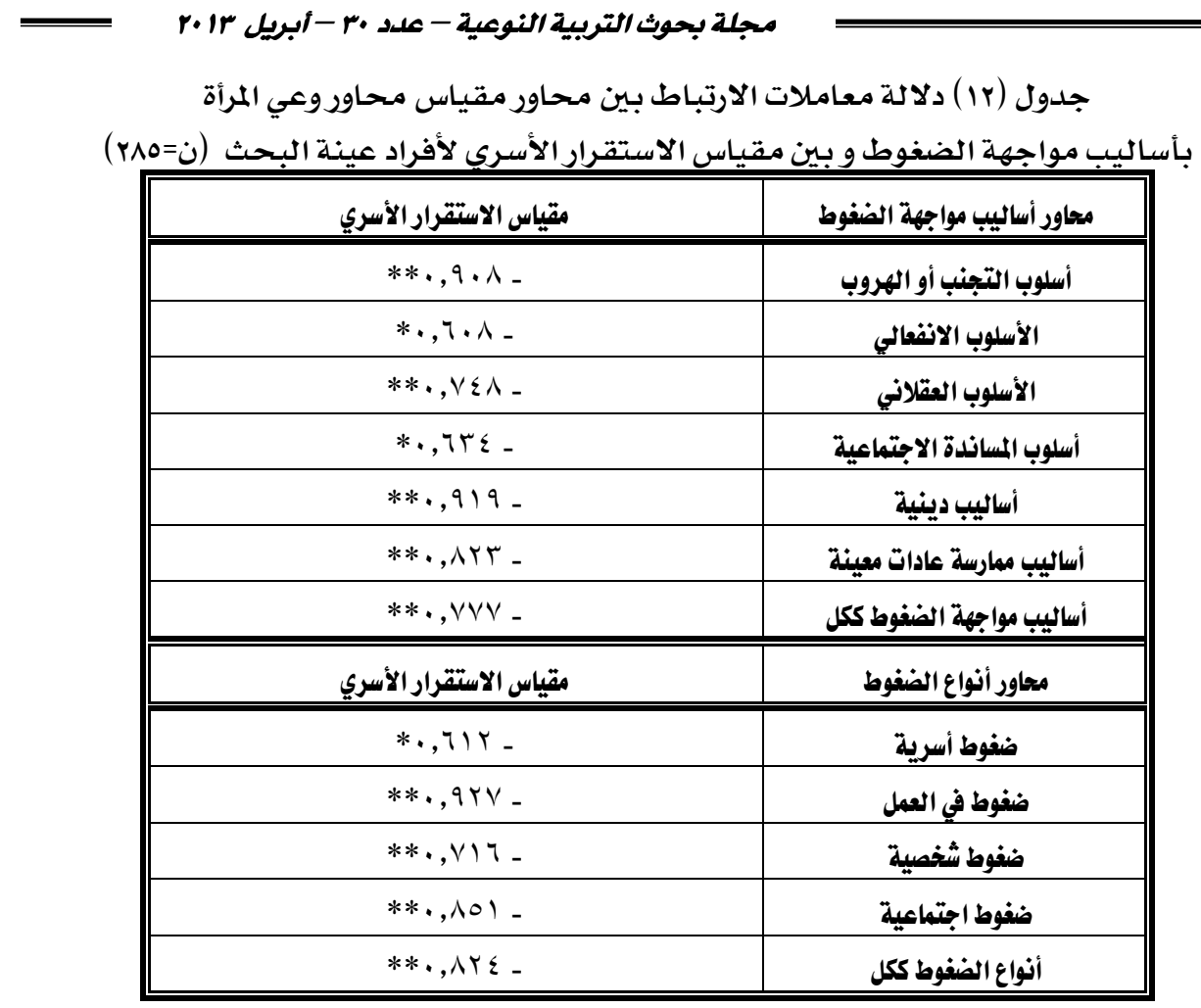

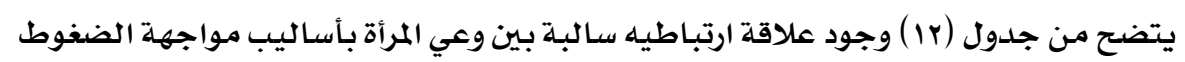

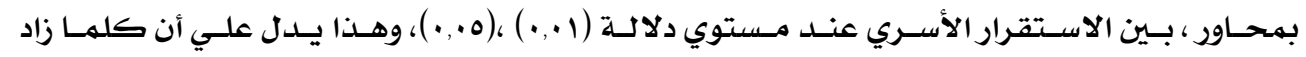

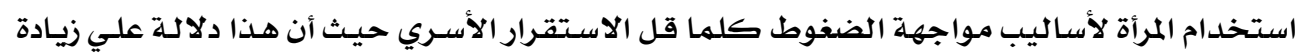

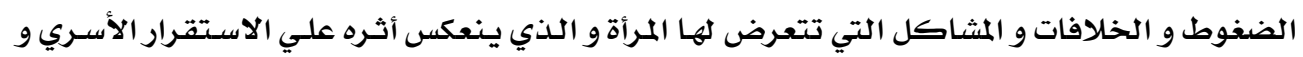

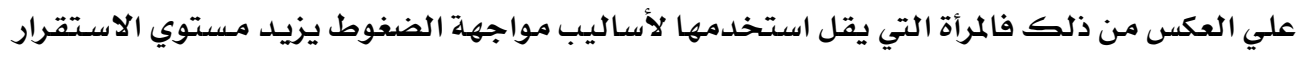

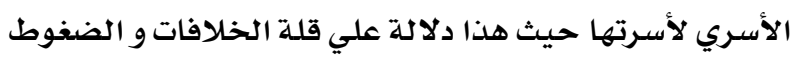

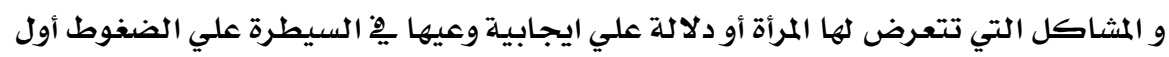

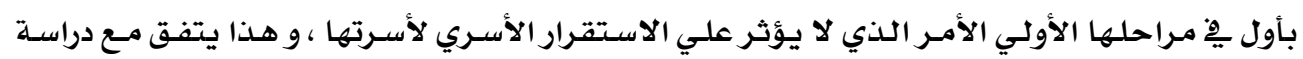
(Holahen\&Moos, 1986)، (Zellars\&Perrewe,2001) تقلل من الضغوط بين أفراد عينة الدراسـة، ( King,1991) وجود علاقة موجبة دالة بـين إستراتيجية

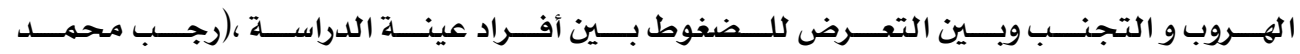

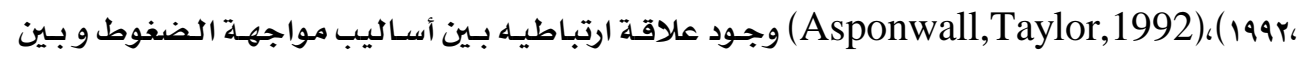
التوافق النفسي و الاجتماعي لأفراد عينة الدراسة .

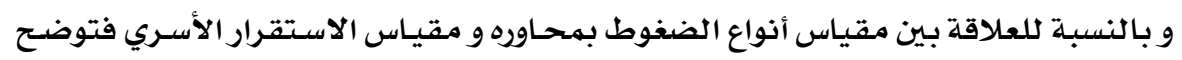

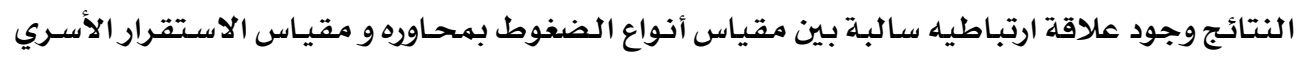




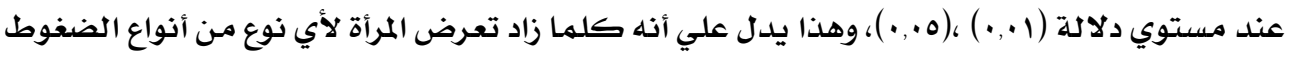

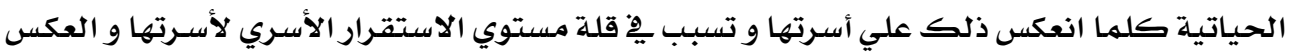

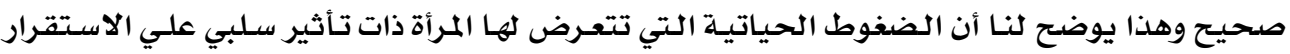

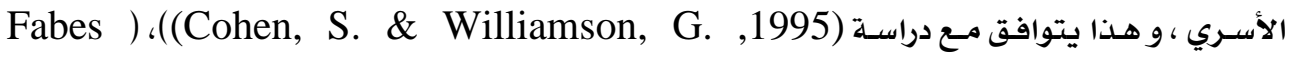

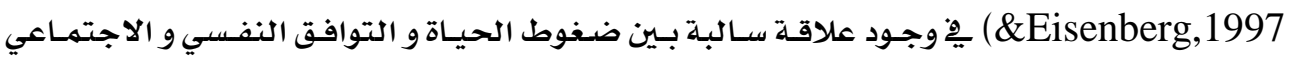

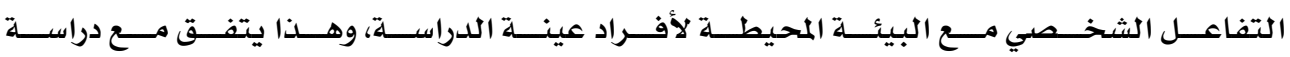
(Higgins\&Endler,1995) الأسلوب الانفعالي لأفراد عينة الدراسة. الفرض الرابع :

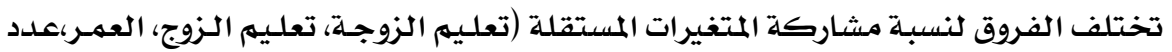

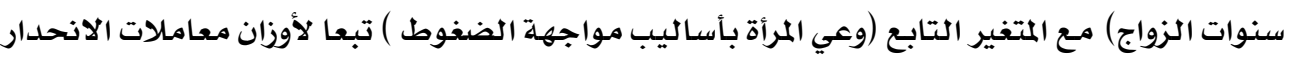
و درجة الارتباط .

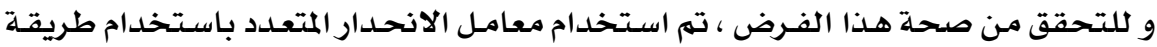

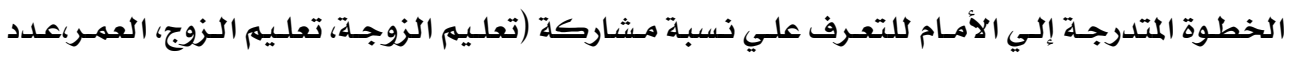

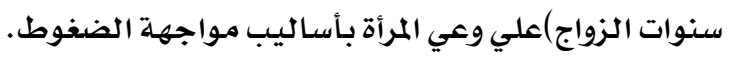
جدول ( س ا ) معاملات الانحدار باستخدام طريقة الخطوة المتدرجـة إلي الأمام للتعرف علي نسبـة

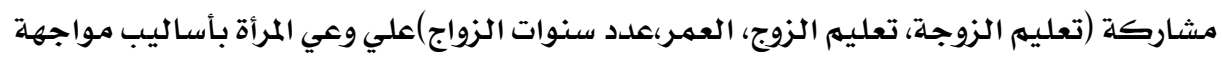

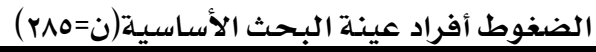

\begin{tabular}{|c|c|c|c|c|c|c|c|c|}
\hline | الدلالة & 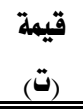 & | معامل & | الدلالة | & | قيمة ف) & نسبة & معامل & المتفير المستقل & \multirow{5}{*}{ الماليب مواجير التابع } \\
\hline$\cdot, \cdot 1$ & 9,114 & •, OVY & •, & $\Delta r, \bullet \xi 1$ & $\cdot, v \leqslant A$ & •,170 & تعليم الزوجة & \\
\hline$\bullet,+1$ & $v, r \leq Y$ & •,รTV & $\cdot, \cdot 1$ & or,97r & $\cdot, 701$ & $\cdot, A l l$ & تعليي الزوج & \\
\hline$\cdot, \cdot 1$ & 7, ov. & $\cdot, 8 \cdot 9$ & $\cdot, \cdot 1$ & $\varepsilon r, 19 r$ & $\cdot, 7 \cdot V$ & •, YYQ & العمر & \\
\hline$\cdot, \cdot 1$ & 0,179 & • r r r & $\cdot, \cdot 1$ & rr,YOI & •, O\& & •, VYV & عدد سنوات الزواج & \\
\hline
\end{tabular}

يتضح من جدول ( س ) ) أن كلا من (تعليم الزوجة، تعليم الزوج، العمر،عدد سنوات الزواج)

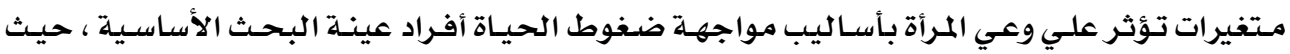

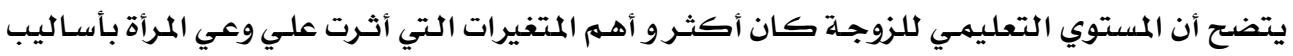

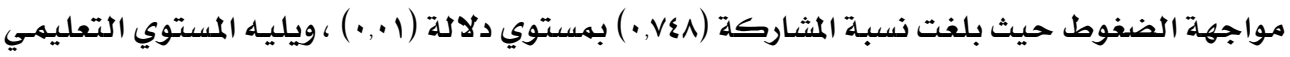

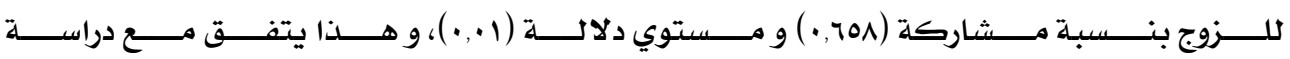

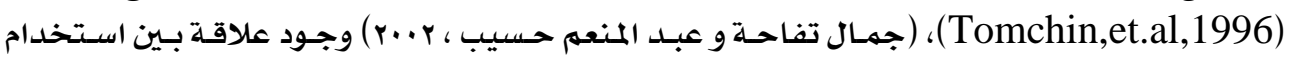

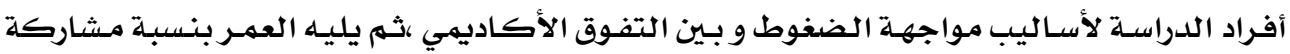




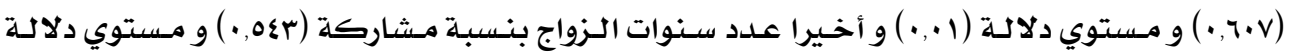

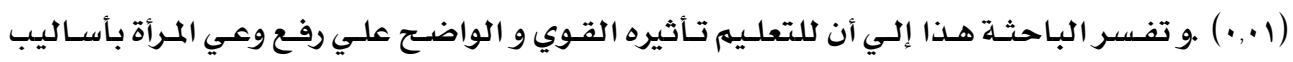

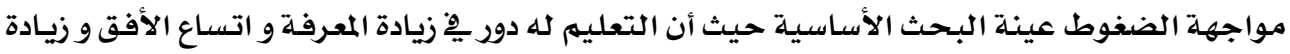

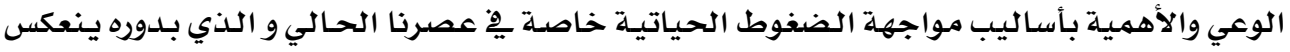

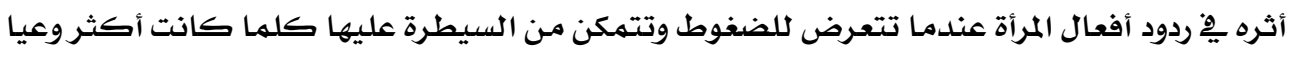

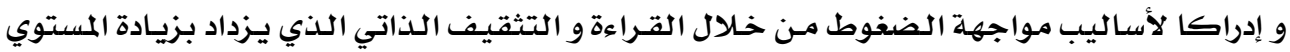

$$
\text { الفعليهي للهمرأة . }
$$

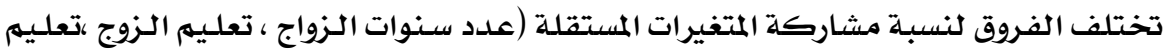

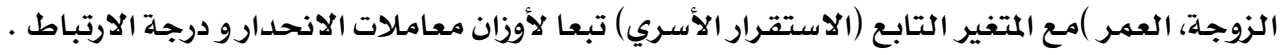

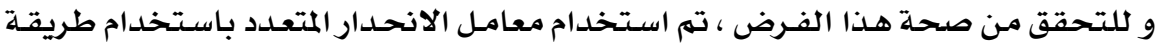

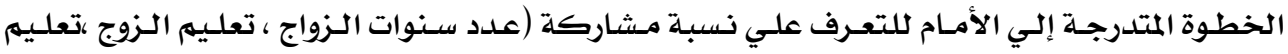

$$
\text { الزوجلة، العمر )علي الاستقرار الأسري. }
$$

\begin{tabular}{|c|c|c|c|c|c|c|c|c|}
\hline الدلالة الد & قيمة (ت) & معامل الانحدار & الدلالة & قيمة ف) & نسبة الشاركة & معامل الارتباط & المتفير المستقل & \multirow{5}{*}{ الالألتفير الابتر } \\
\hline$\bullet,+1$ & А,\&IT & •, oro & $\cdot, \cdot 1$ & $r \cdot, r v r$ & •, riv & $\cdot, \wedge \leqslant 7$ & عدد سنوات الزواج & \\
\hline$\cdot, \cdot 1$ & $v, \cdot \sum \eta$ & $\cdot, \llbracket \leftleftarrows 7$ & $\cdot, \cdot 1$ & $\Sigma 9,7+\wedge$ & •, 7rq & $\cdot, A \cdot \cdot$ & تعليم الزوج & \\
\hline$\bullet,+1$ & $7, \cdot \leqslant 9$ & •, & $\cdot, \cdot 1$ & $r q, 091$ & $\cdot, 07 \mathrm{~V}$ & •, vor & تعليم الزوجة & \\
\hline$\cdot, \cdot 1$ & $0,0 \& Y$ & •, TrY & •, & $r \cdot, \vee / q$ & •, Orr & •, VYT & العمر & \\
\hline
\end{tabular}

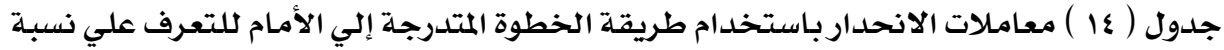

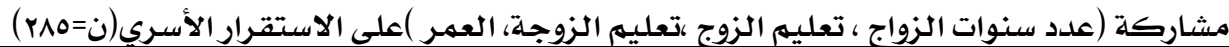

يتضح من جدول ( \& 1) أن كلا من (عدد سنوات الزواج ، تعليم الزوج ،تعليم الزوجة، العمـر )

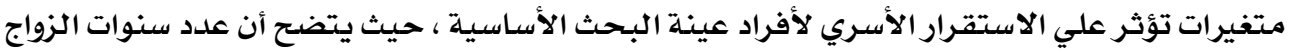

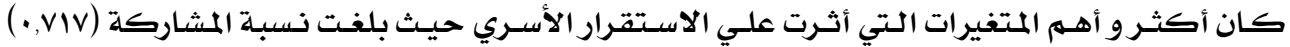

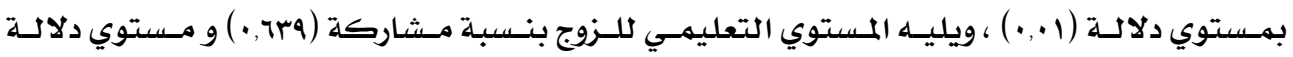

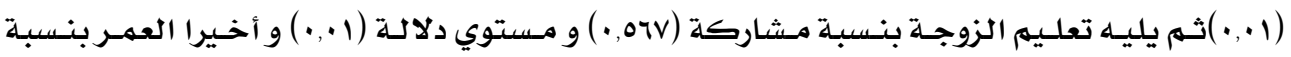

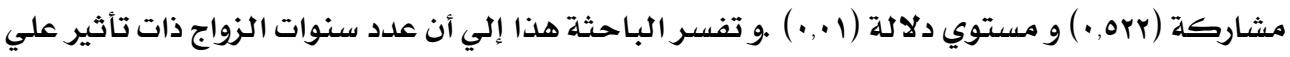

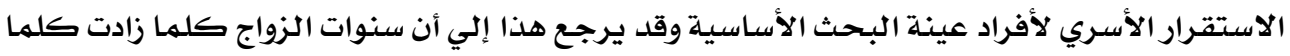

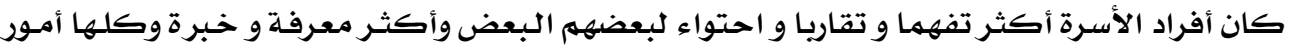

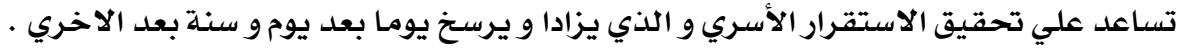


تختلـف الأوزان النسـبيـة لأولويـة ترتيـب محسـاور مقيـاس أنـواع الـضغوط لـــي أفـراد عينــة

جدول (10) الوزن النسبي لمحاور أنواع الضغوط تبعا لأولوياتها لدي الأفراد عينة البحث

\begin{tabular}{|c|c|c|c|}
\hline الترتيب & النسبة المئوية./ & الوزن النسبي & أنواع الضفوط \\
\hline الثاني & $\%$ \%०,\& & rrq & ضفوط أسرية \\
\hline الأول & $\%$ \%A,I & rro & ضفوط في العمل \\
\hline الثالث & $\% r r, \Lambda$ & min & ضفوط شخصية \\
\hline \multirow[t]{2}{*}{ الرابع } & $\%$ $\%$, A & $r+\varepsilon$ & ضغوط اجتماعية \\
\hline & $\% 1 .$. & Irrq & المجموع \\
\hline
\end{tabular}

يتضـح مـن الجـدول (10) اختتلاف أولويـات محساور مقيـاس أنواع الضغوط لـدي الأفراد عينـة

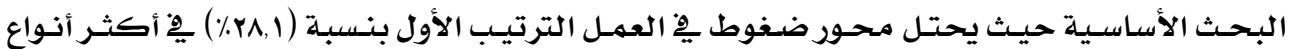

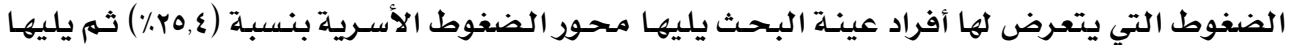

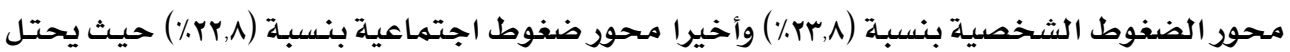

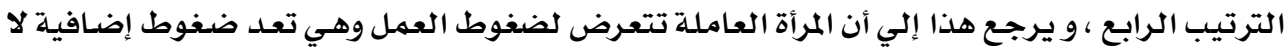

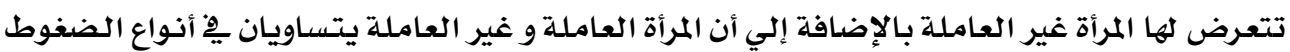

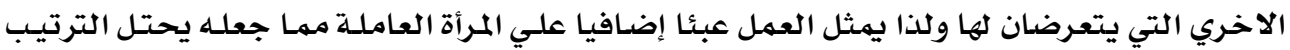

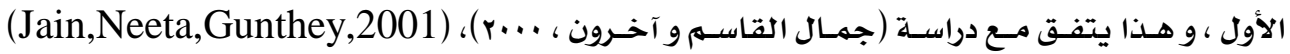

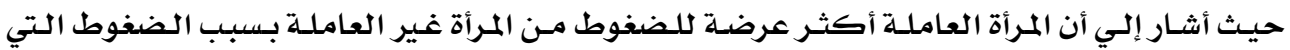

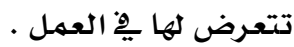
الفرض السابع :

تختلف الأوزان النسبية لأولوية ترتيب محاور مقياس وعي المرأة بأسـاليب مواجهـة الضغوط

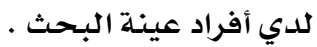




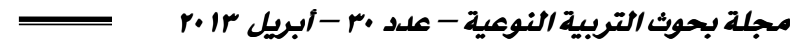

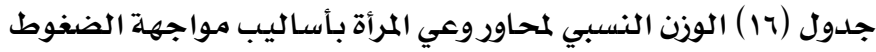

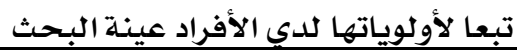

\begin{tabular}{|c|c|c|c|}
\hline الترتيب & النسبة المئوية/٪ & الوزن النسبي & \\
\hline السادس & $\% 1 \varepsilon, \wedge$ & ral & أسلوب التجنب أو الهروب \\
\hline الخامس & $\% 10, r$ & $r+1$ & الأسلوب الانفعالي \\
\hline الأول & $\% 19,8$ & $r A \mid$ & الأسلوب العقلاني \\
\hline الثاني & $\% 1 Y, 1$ & T\&V & أسلوب المساندة الاجتماعية \\
\hline الرابع & $\% 17$ & rio & أساليب دينية \\
\hline \multirow[t]{2}{*}{ الثالث } & $\% 17,9$ & rrr & أساليب ممارسة عادات معينة \\
\hline & $\%$ & 1971 & المجموع \\
\hline
\end{tabular}

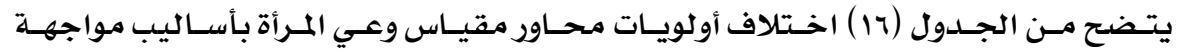

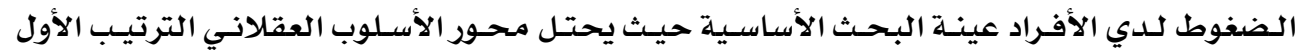

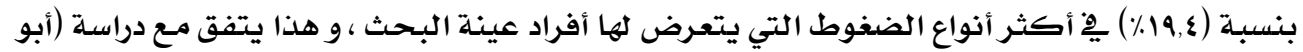

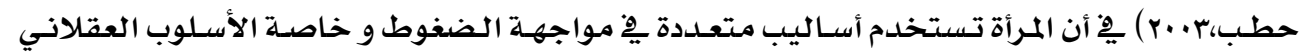

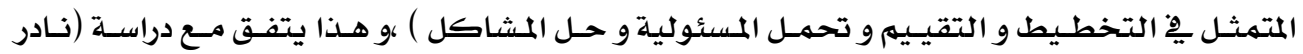

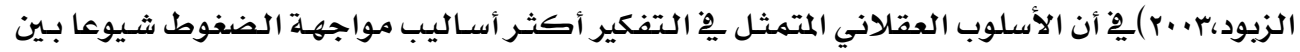

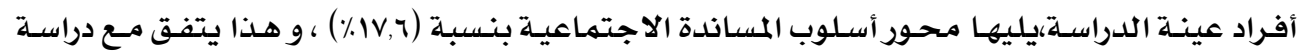

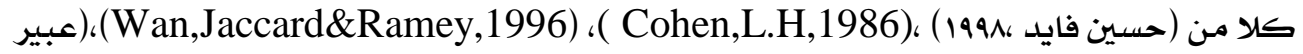

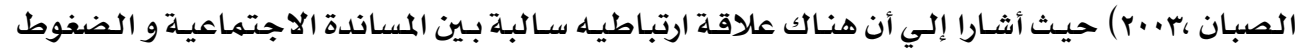

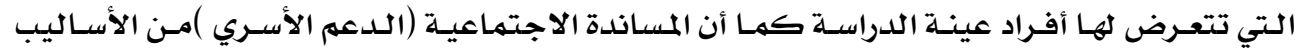

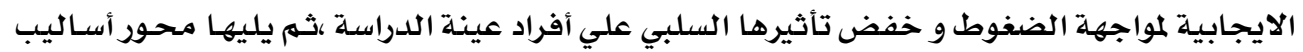

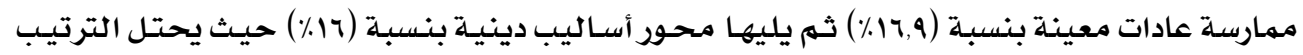

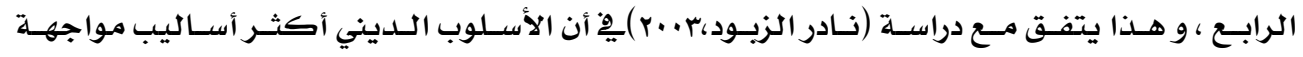

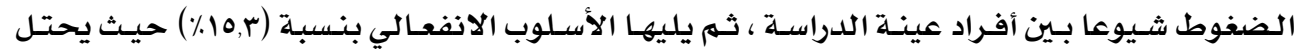

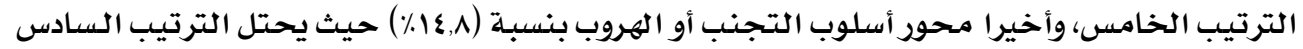

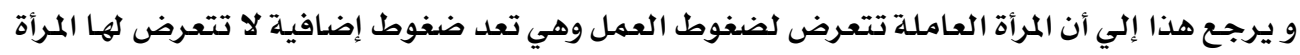

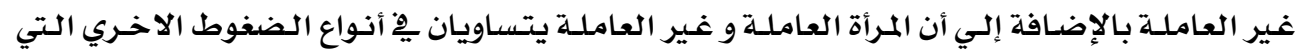

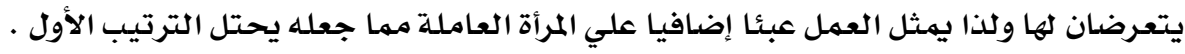

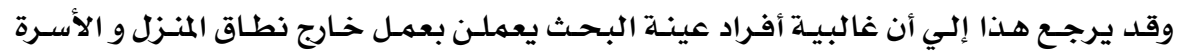

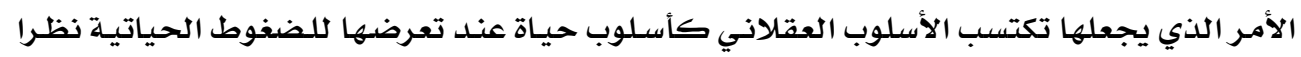

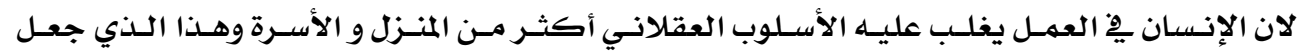

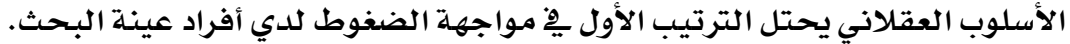




$$
\text { توصي الباحثة بما يلي : }
$$

ا- إعداد البر امـج الارشاديه ضمن تخصص قسمى إدارة مؤسسـات الأسـرة و الطفولـة لتوعيـة المرأة

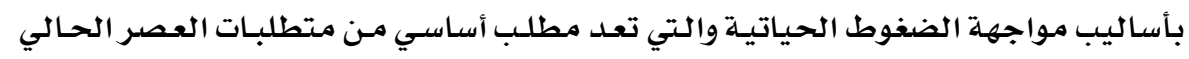

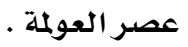

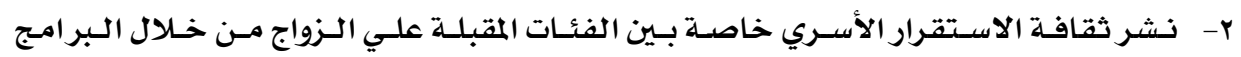

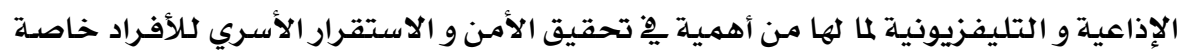

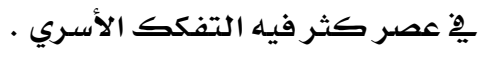

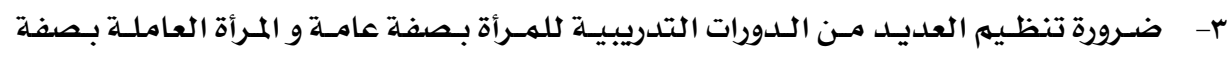

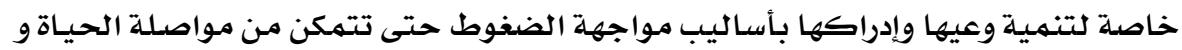

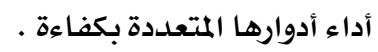

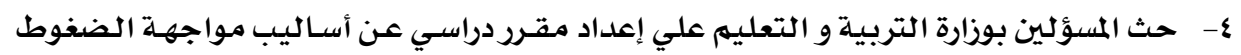

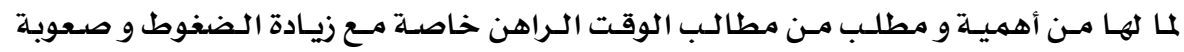
الحياة و كمدخل من مداخل التنمية البشريية . 
1- إبراهيهم عبد الستار (1991) ) : الاكتئاب :اضطراب العصر الحديث فهمه وأساليب علاجه- عالم المعرفة -

$$
\text { المجلس الوطني للثقافة و الفنون بالكويت . }
$$

r- المعجم الوجيز (ra91) ) مجمـع اللغة العربية - الهيئة العامـة لشؤون المطابع الأميرية - القاهرة .

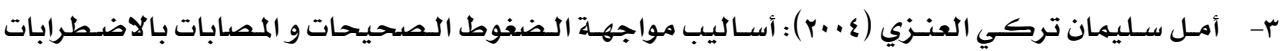
النفسجسمية السيكوسوماتية " دراسة مقارنـة - رسـانة ماجستير غير منشورة - كليـة التربيـة قسمى علـم

$$
\text { نفس - جامعة الملك سعود . }
$$

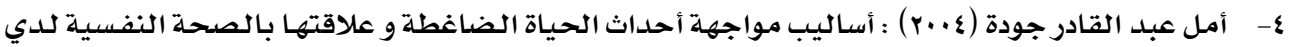
عينـة من طلاب و طالبـات جـامعـة الاقصي - بحث مقدم الي مـؤتهر التربـوي الأول "التربيـة ِِِ فلسطين و

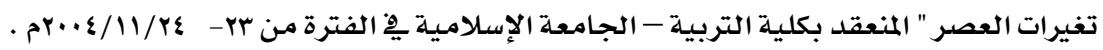

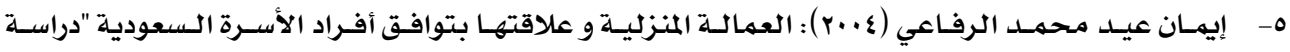
ميدانية بمنطقة مكة المكرمـة" رسـالة ماجستير غير منشورة - قسم السكن و إدارة المنـزل - كليـة التربيـة

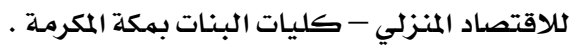

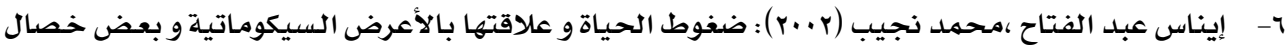

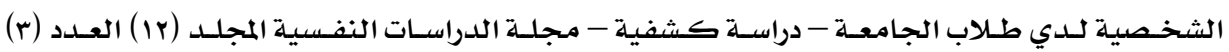
القاهرة .

V- - جلال الدين الغزاوي (1990) ؛ مهارات الممارسة يخ العمل الاجتماعي - الكويت - مكتبة ذات السلاسل .

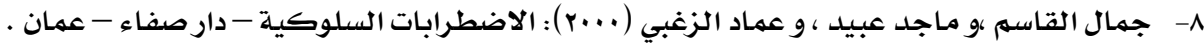

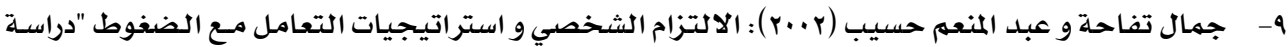
مقارنة البلدو و الحضر " - مجلة الإرشاد النفسي - جامعة عين شمس - العدد الخامس عشر •

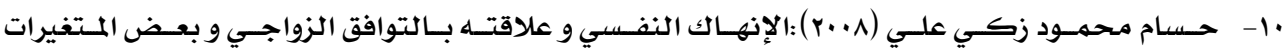

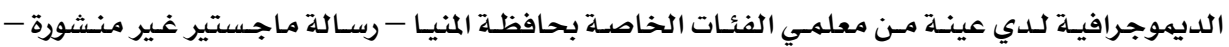
كلية الآداب - جامعة المنيا .

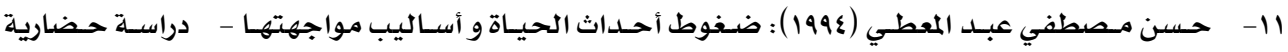
مقارنة يف المجتمـع المصري و الاندونيسي - المجلة المصرية للدراسـات النفسية - العدد الثامن.

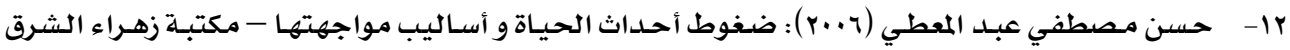
-

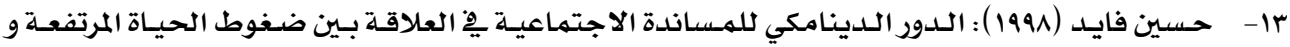

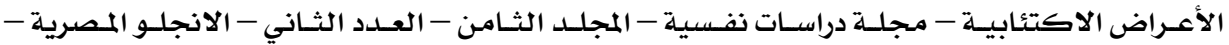
القاهرة . 


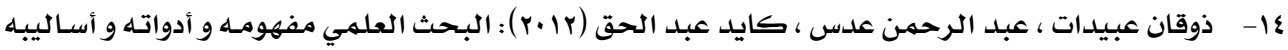
- طها - دار أسـامـة للنشر و التوزيـع - جدة.

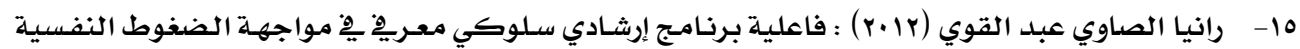

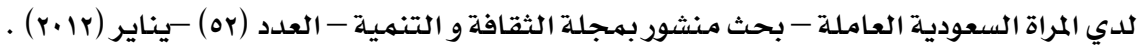
17 - رجـب علـي شـعبـان (1990) : العلاقـة بـين أسـاليب التعامـل الاقداميـة و الاحجاميـة مـع الأزمـات و التوافـق

النفسي و بعض سمات الشخصية - الهيئة المصرية العامـة للكتاب - مجلـة علهم النفس - المجلد (ع ) . IV- رجب محمد (1994) : العلاقة بين أسـاليب التعامل الاقدامية و الاحجامية مـع الأزمات و التوافق النفسي و بعض سمات الشخصية - مجلة علم النفس - العدد الرابع و العشرون - الهيئسة المصرية العامـة للكتاب القاهرة . رجب محمد (1990): الفروق الجنسية و العمـريـة ِِ أسـاليب التكيف مـع المواقف الضـاغطة - مجلسة علمم النفس - العدد الخامس و الثلاثون - الهيئة المصرية العامة للكتاب - القاهرة .

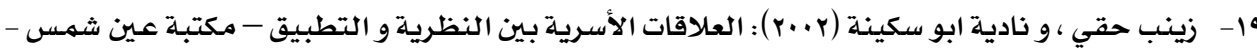
القاهرة .

•r- - سميحة كرم توفيق (1997) ) مدخل العلاقات الأسريـة - دار المعرفة الجامعية - القاهرة .

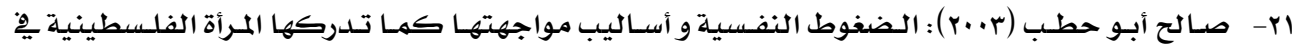
محافظة غزة - رسالة ماجستير غير منشورة - جامعة الاقصي بغزة زوليه

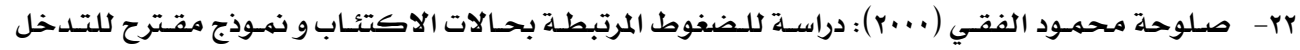
المهـني مـن منظـور خلدمسة الفـرد - رسـالة دكتـوراه غـير منسشورة - كليـة الخدمسة الاجتمـاعيـة - جامعـة حلوان .

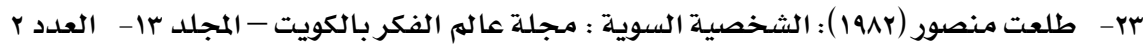

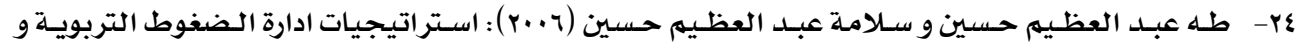

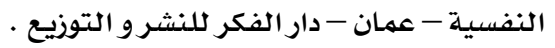

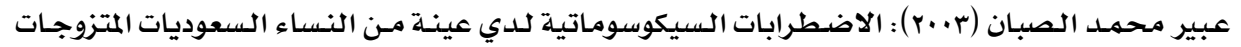
- YO العاملات يِّ مدينتي مكة المكرمة و جدة - رسالة دكتوراه غير منشورة - جامعة أم القرى - قسهم التربيـة و علم النفس - المملكة العربية السعودية .

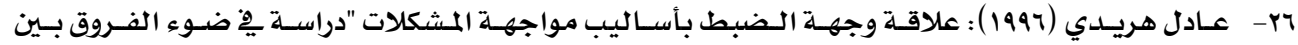
الجنسـين " - مجلة بحوث كلية الآداب بجامعة المنوفية - العدد السادس و العشرون.

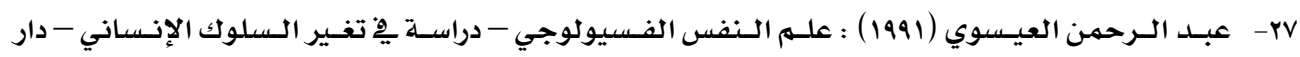
النهضة العربية - القاهرة .

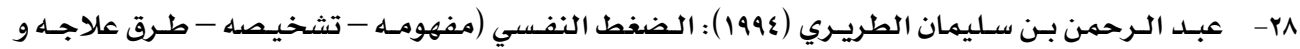
مقاومته ) المملكة العربية السعودية - مطابع شركة الصفحات الذهبية المحدودة . هץ- عبد المطلب القريطي ،و عبد العزيز الشخصي (1994) : مقياس الصحلة النفسية للشباب - مكتبـة الانجلو المصرية - القاهرة . 


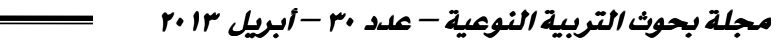

• ب- عبد الحميد الشـاذلي (1999) : الصحة النفسية و سـيكولوجية الشخصية - الإسكندرية - المكتب العلمسي.

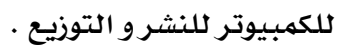

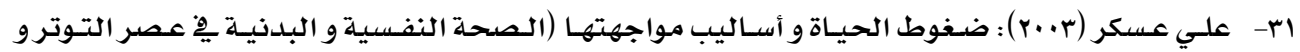

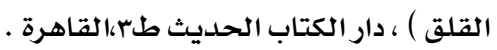

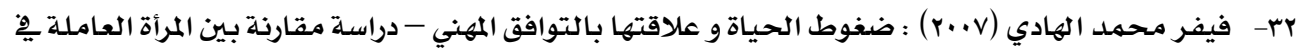

المجال الأكاديهي و المجال الإداري - رسالة دكتوراه غير منشورة - كلية الآداب - جامعة عين شمس. بr- فيفيان فايز إبراهيم (1991 ): دراسـة العلاقات بين ضغوط الو الدية و التوافق الشخصي وال اجتمـاعي لدي تلاميذ المرحلة الابتدائية - رسالة ماجستير غير منشورة - معهد الدراسـات العليا للطفولة - جامعـة عـين

شمس

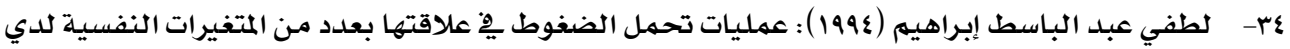
المعلمين - جامعة قطر - مجلة مركز البحوث التربوية - العدد الخامسة السنة الثالثة .

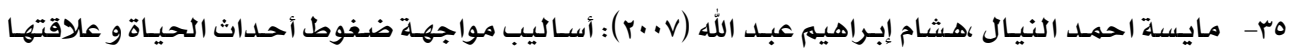

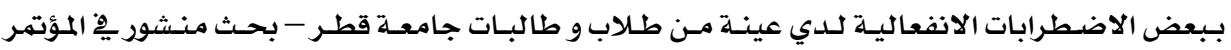

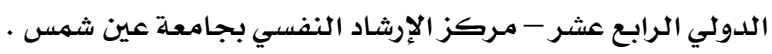

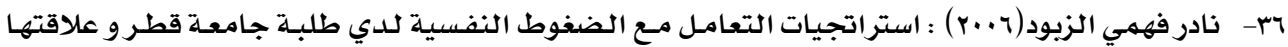

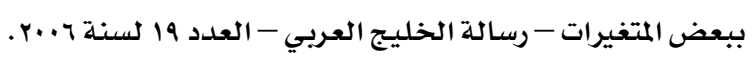

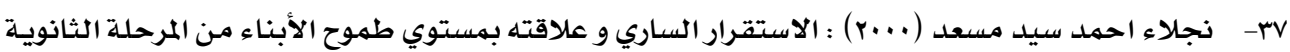

بمسحافظة القليوبية - رسالة ماجستير غير منشورة - كلية الاقتصاد المنزلي - جامعة المنوفية .

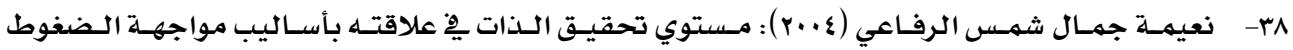

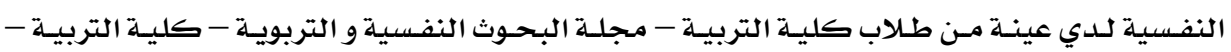

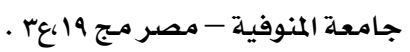

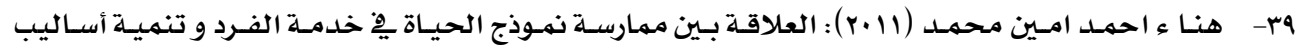
مواجهـة الضغوط الحيـاتيـة - للطالبـة الجامعيـة المتزوجـة - دراسـة مطبقـة علـي طالبـات قسم الدراسـات

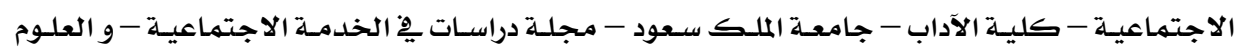

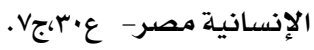

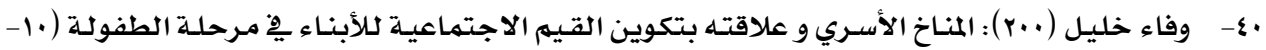

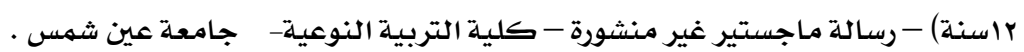

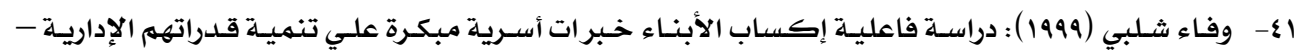

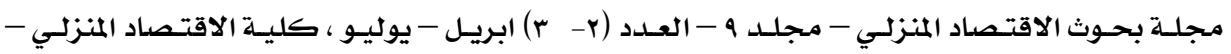
جامعة المنوفية .

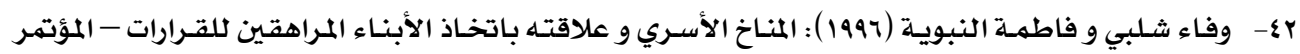
المصري الأول للاقتصاد المنزلي - كلية الاقتصاد المنزلي - جامعة المنوفية . 


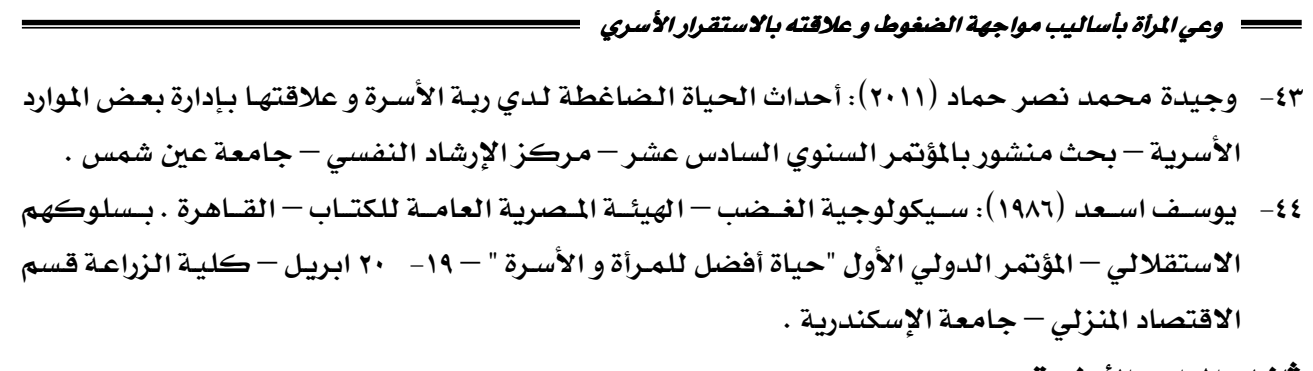

ثانيا : المراجع الأجنبية :

1- Asponwall, L., Taylor, S. (1992): Modeling cognitive adaptations: A longitudinal investigation of the impact. Journal of personality and social psychology, vol (63), No (6).

2- Asted_Kurki, Friedman, M., Paavilainen, Termmentie and Paunonen Il mohen. M. (2001): Assessment of strategies in family tested by finish families. International Journal of Nursing studies 38.

3- Cohen, L.H. (1987): Life stress and adjustment effects of life events experienced by young adolescents and their parents developmental psychology 23(4).

4- Cohen, R.J. (1994): Psychology \& Adjustment values, culture, and change. Boston Allyn and Bacon.

5- Cohen, S. \& Williamson, G. (1987): stress and infections disease in human. Psychological Bulletin. Vol (109), No (1).

6- Constance, H. (2004): Intergenerational Transmission of Depression Test of an Interpersonal street Model in community sample, Journal of counseling and clinical psychology.

7- Fabes R. \& Eisenberg, N. (1997): Regulatory control and adults, stress-related responses to daily life events, Journal of personality and social psychology. Vol. (73), No (5).

8- Frone, et.al (1991): Relationship of work and family stressors to Psychological Distress. The independent moderating influence of social support. Mastery active coping and self focused attention. Journal of Social Behavior and Personality. Vol (6) (7).

9- Fuber, b.a (1984): stress and burnout in suburban teachers. Journal of Educational Research. (77) (6).

10-Gunthert, K. \& Cohen, L. (1999): The role of Neuroticism in daily stress and coping, Journal of personality and social psychology, vol (77), No (5). 
11-Heaney, C. \& RYN, M. (1990): Broadening the scope of work site stress programs, American, Journal of Health Promotion. Vol (4), No (6).

12-Higgins J.E, \& Endler, N.S. (1995): Coping life stress, and psychological and somatic distress. European, Journal of personality, 9(4).

13-Holahan, C \& Moos, R. (1985): Life and health personality coping and family support in Stress Resistance, Journal of personality and social, vol (49), No (3).

14-Holahen, \& Moos R. (1986): personality coping and family resources in stress resistance: A longitudinal analysis. J. of per. And soc. Psych. Vol (51), No (2).

15-Jain, Neeta, Gunthey, Ravi. (2001): Marital adjustment and problem among working women-social science international, 17,1,55.

16-James M. Karls \& Karin E.W Andrel (1993): person in Environment, in Encyclopedia of social work, Naswpress, 19th ed.

17-James, H. (1993): stressful life events, locus of control social support networks as predicators of malad justment among collede freshmen. Reports-Research conference Pennsylvania April 1. Eric.

18-King, K. (1991): Life events, stress and copying strategies of secondary school students in Hong Kong-an exploratory study. http://www.fedcugd.edu.hk/ceric/cuma/91Lkkwong.

19-Kobssa, S \& puccet, M (1983): Personality and Social Resources in Stress Resistance Journal of personality and social psychology, vol (54), No (4).

20-L. Glynn, W.L Glynn, T Newman, (1981): Group Cognitive Behavior Therapy for Anorexia Nervosa: A case for treatment European _Eating Disorders Review, vol (7), No (5) November.

21-Martin, R.A Kazarian \& et.al (1995): perceived stress life events, dysfunctional attitudes and depression in adolescent psychiatric in patients, Journal of Psychopathology and Behavioral Assessment 17(1).

22-Rothrock , N et.al (2003): coping strategies in patients with interstitial crystitis: relationships with quality of life and depression Journal of Urol, vol (169), No (1).

23-Smith J. (1993): understanding stress and coping New York: Macmllan, Inc.

24-Tomchin, et.al (1996): coping and self concept: Adjustment patterns in gifted adolescents, Journal of secondary gifted education. Vol (8), No (1).

25-Victories Websters (1994): New World Dictionary, New York: Prentice Hall. 
26-Wan, C. Jaccard, J. \& Ramey S.L. (1996): The relationship between social support and life satisfaction as a function of family structure. Journal of Marriage and the family. 58(2).

27-Zellars, K. \& Perrewe, P. (2001): Affective personality and the content of emotional social support: Coping in organizations J. of app. Psch. 